\title{
THE LANGUAGE OF MAINSTREAM FEMINISM IN MEDIA: AN ANALYSIS OF THE FREEDA MEDIA AND LOLA FACEBOOK PAGES
}

Rebecca Boraso

Adelina Sánchez Espinosa (Universidad de Granada)

Rita Monticelli (Università di Bologna)

Instituto Universitario de Estudios de las Mujeres y de Género (Universidad de Granada)

2019

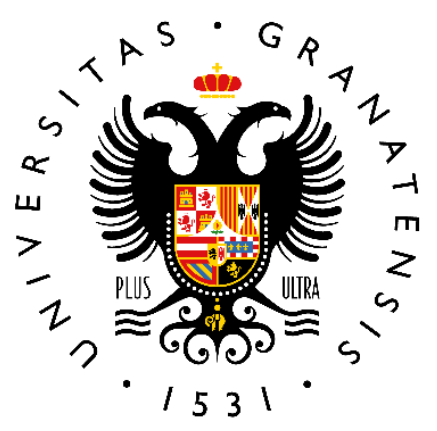

\section{UNIVERSIDAD \\ DE GRANADA}





\section{THE LANGUAGE OF MAINSTREAM FEMINISM IN MEDIA: AN ANALYSIS OF THE FREEDA MEDIA AND LOLA FACEBOOK PAGES}

Rebecca Boraso

Adelina Sánchez Espinosa (Universidad de Granada)

Rita Monticelli (Università di Bologna)

Instituto Universitario de Estudios de las Mujeres y de Género (Universidad de Granada)
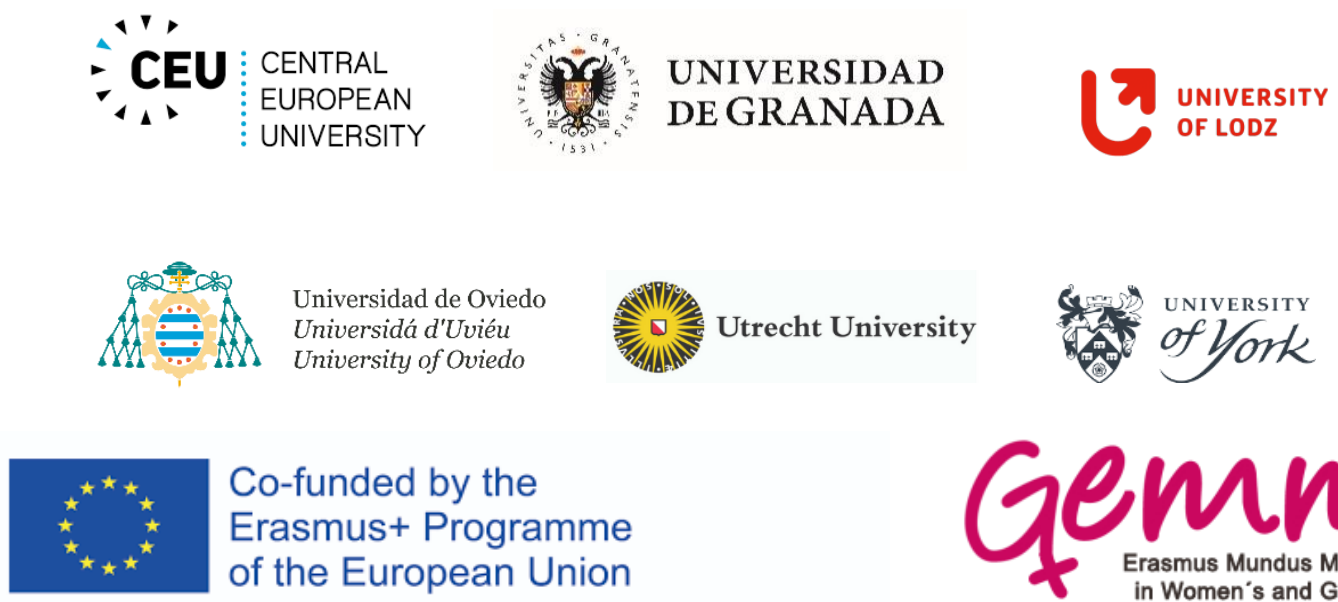

Utrecht University

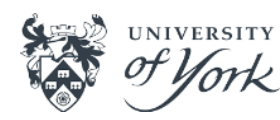



INDEX

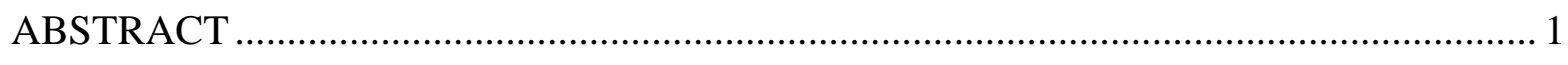

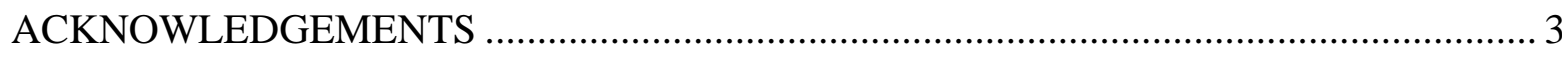

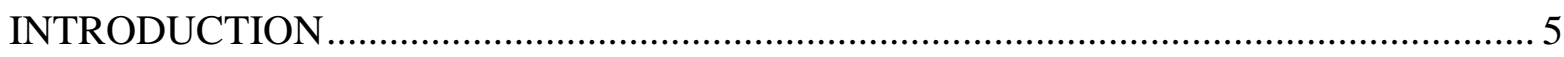

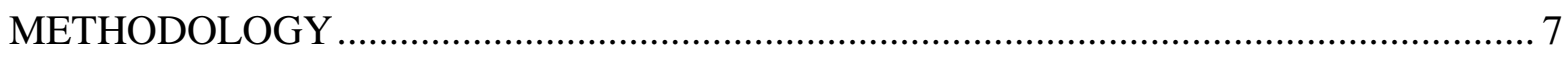

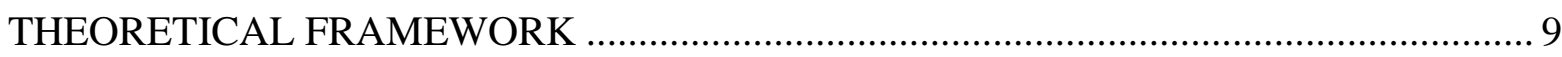

1.1 CONTEMPORARY FEMINISM: BETWEEN A FOURTH WAVE AND

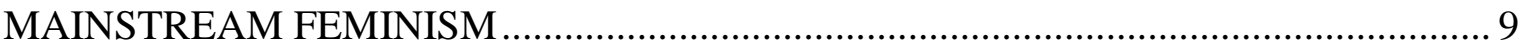

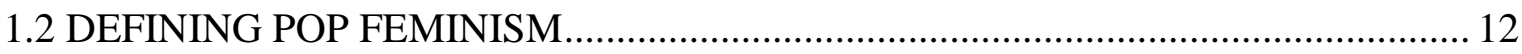

1.3 GENDER AND ADVERTISING: FEMVERTISING …......................................... 17

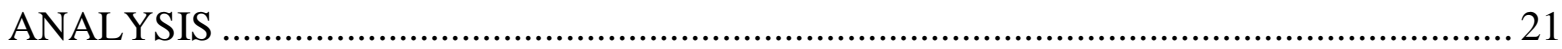

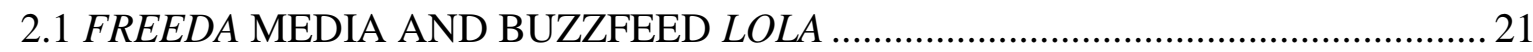

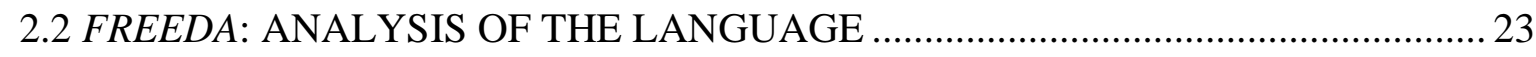

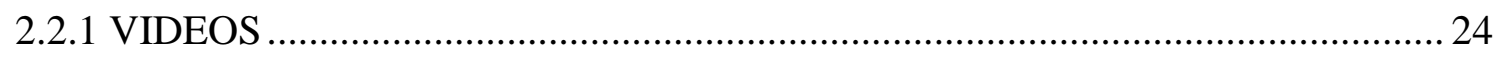

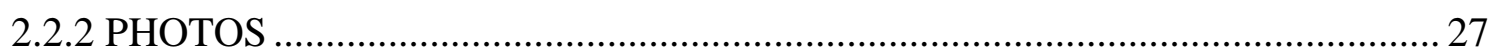

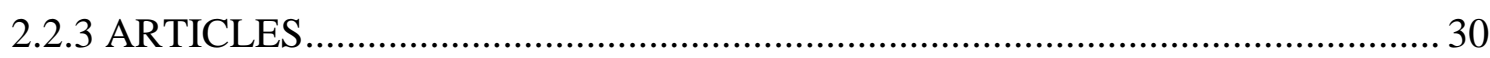

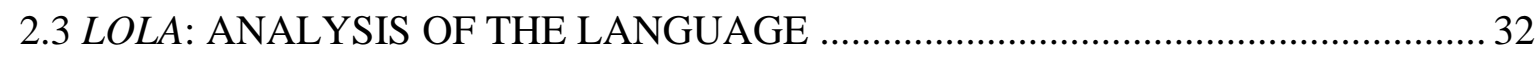

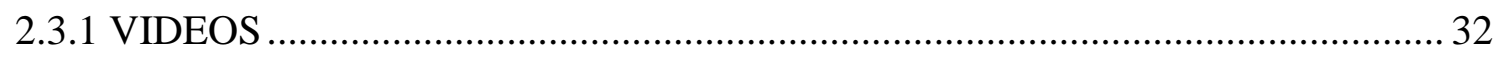

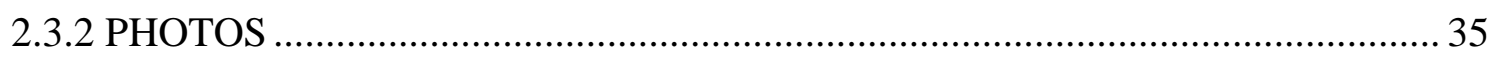



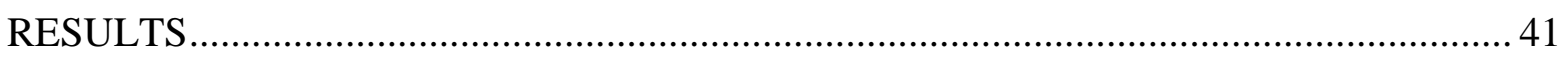

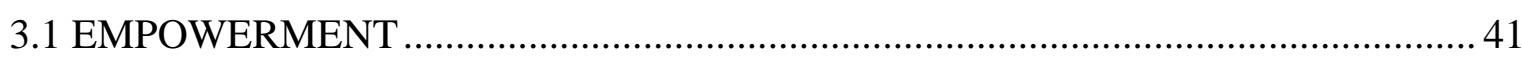

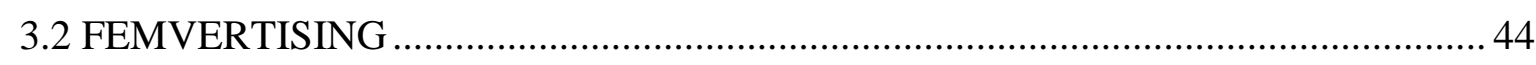

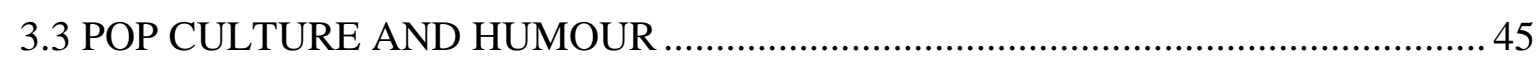

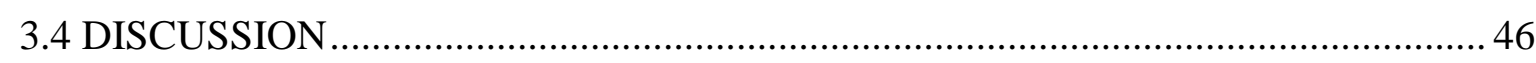

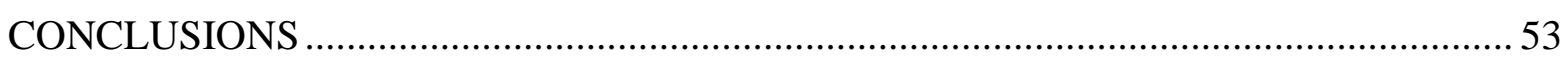

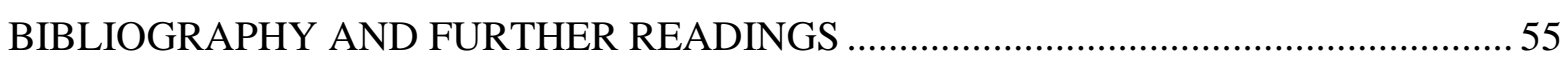

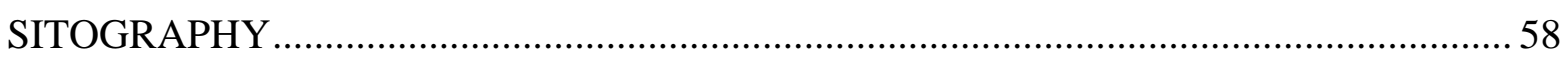




\begin{abstract}
Feminism has nowadays reached its fourth wave and some claim that this wave is taking place online. Social media are sites that have known a strong development in the last years, while similarly feminism has known a rise in popularity. In fact, in recent times the feminist movement has known a rise in popularity on mainstream platforms and on social media, too, becoming by all means a trend. This sudden rise has led to the creation of new feminist pages that, according to their peculiar features, can be defined as pop feminist.

The aim of this dissertation is to firstly give a definition of mainstream or pop feminism, and of the concept of "femvertising". Next, it will analyse the language used by some of these supposedly feminist media and investigate how and why they connect with their users.

Two Facebook pages have been selected in order to compare two similar yet different approaches: an Italian one, Freeda Media, and a Spanish one, Buzzfeed LOLA. Through qualitative research, my own participant observation of these media, and the aid of social network analysis and data collection, the paper will examine the words, the topics and the strategies employed to engage with a certain target of women online.
\end{abstract}

\title{
RESUMEN
}

El feminismo ha alcanzado hoy su cuarta ola y algunos afirman que esta ola se está produciendo online. Las redes sociales son sitios que han experimentado un fuerte desarrollo en los últimos años, mientras que el feminismo también ha experimentado un aumento en la popularidad. De hecho, en los últimos tiempos, el movimiento feminista ha conocido un crecimiento de la popularidad en las plataformas principales y en las redes sociales, convirtiéndose en una tendencia. Este aumento repentino ha llevado a la creación de nuevas páginas feministas que, según sus características peculiares, pueden definirse como pop feministas.

El objetivo de esta tesis es en primer lugar dar una definición de feminismo mainstream o pop, y en segundo lugar dar una definición del concepto de "femvertising". A continuación, se analizará el lenguaje utilizado por algunos de estos medios supuestamente feministas y se investigará cómo y por qué se conectan con sus usuarios. Se han seleccionado dos páginas de Facebook para comparar dos enfoques similares pero diferentes: uno italiano, Freeda Media, y uno español, Buzzfeed LOLA. A través de la investigación cualitativa, mi observación participante de estos medios y la ayuda del análisis de redes sociales y la recopilación de datos, 
el documento examinará las palabras, los temas y las estrategias empleadas para interactuar con un determinado objetivo de las mujeres en línea. 


\section{ACKNOWLEDGEMENTS}

This thesis is the result of two challenging years of learning and de-constructing myself between Italy and Spain through the eyes of many different cultures and experiences.

I would first like to thank my thesis advisor, Professor Adelina Sánchez Espinosa, coordinator of the GEMMA Master at the University of Granada. She has always been available to solve any problem or question I had during my research, and above all she reassured me when bureaucracy seemed to be overwhelming.

Secondly, I would like to thank my co-advisor, Professor Rita Monticelli, coordinator of the GEMMA Master at the University of Bologna. She played a fundamental role in giving me not only the basis for a gender perspective during my first year of master, but also in learning how to deal with public institutions.

A special thank goes to my colleagues of the GEMMA Master, both in Bologna and in Granada. Their aid and help in finding, developing and deconstructing my ideas and myself have been an important part of my research process. What I learnt outside the classroom has been more valuable than what I could find in any book.

I would also like to thank my friends back home in Verona: Cecilia, Gloria, Francesca, Laura, Elena and Carlotta. They have always supported and cheered for me from the distance while I was embarking in this experience in Granada: they taught me that friendship and sisterhood go beyond the oceans that keep us apart.

Finally, I express my profound gratitude to my family and especially my parents, Luigina and Nicola, who have always funded and believed in my education. Moreover, they allowed me to make my own choices and mistakes, even when they did not fully understood them. Thank you for your never ending support and for providing me with the first tools to read the world. This accomplishment would not have been possible without you.

Grazie. 


\section{INTRODUCTION}

In recent years, feminism has been rediscovered by mainstream culture and has consequently started to gain a higher degree of attention in various areas, such as politics, fashion, and media. Feminism as a movement and set of values seems to have finally reached a much needed widespread attention, which could be useful to export ideas to a larger public. This alleged spread of feminism and feminist topics in mainstream culture is proved, for instance, by the rise of the \#Metoo movement or by the women's organisations and marches like \#Niunamenos, all of which expanded all over the world and managed to obtain a substantial consideration from the media. However, the late legitimisation of feminism among a wider audience is also due to the use of feminism in pop culture and advertising. The appearance of feminist slogans on clothes or fashion lines, the increased presence of tough, strong, independent women on screen, the recurring messages of girl empowerment in advertisements, and the endorsement of feminism by celebrities are just a few examples of the means through which feminism has earned a place under the spotlight.

Speaking of spotlights, feminism is lately spreading on the internet, as many different online platforms prove: feminist themes appeared on blogs, websites like YouTube, social media such as Facebook, Instagram and Twitter, and technology came to have a relevant weight in feminist issues ${ }^{1}$, both positively and negatively.

The present dissertation intends to examine pop feminism on social media through the observation of some selected content from two Facebook pages, Freeda media and Buzzfeed LOLA. These two examples are respectively an Italian page and a Spanish one, both of which self-describe themselves as pop feminist. The aim will be to encounter the type of language, strategies and characteristics used by these pages online to connect with their users and share their content, and consequently trace a general conclusion about this type of feminism.

In order to do that, this work has been divided in sections: firstly, the methodology of the analysis will be provided. Here we can find the approach and the process of examination of the samples.

\footnotetext{
${ }^{1}$ Wallace, K. (2014). How technology helps feminism and poses challenges - CNN. [online] CNN. Available at: https://edition.cnn.com/2014/03/18/living/technology-empowering-women-identity/index.html [Last Accessed: 8 Sep. 2019].
} 
Secondly, this work will supply some historical and theoretical background about feminism up until the current definitions of pop feminism, and how they interlace with the concepts of postfeminism and neoliberal feminism.

The third section will be dedicated to the concept of "feminist advertising", also known as femvertising (Skey, 2014), and how it connects to mainstream feminism.

The following chapter will be concerned with the analysis of Freeda and LOLA's language through a selection of posted content on their main social media, Facebook. The analysis will include selected videos, images and articles shared by the two pages.

Finally, a results and discussion section will be offered, and it will present the main characteristics of pop feminist language that emerged from the examples studied. After that, the dissertation will conclude presenting the final outcomes of the discussion of the data, arguing that pop feminism online uses recurring themes and topics related to pop culture in order to maintain its visibility. 


\section{METHODOLOGY}

This dissertation aims to analyse the existing relationship between two social media pages, Freeda Media and Buzzfeed LOLA, and their presence on social media. As they present themselves as pop feminist pages, the intention is to examine the type of language they use, the concepts they highlight and how, in order to engage with their target audience. In the case of Freeda, as will be explained further on in this paper, examples of sponsored posts will be provided and interpreted according to the editorial mission that Daria Bernardoni, editor in chief, provides. In regard to the other page, Buzzfeed LOLA will offer instead a Spanish viewpoint on pop feminism online through its posts.

My analysis has been visual and textual, as the data considered included different kinds of content: videos, pictures and articles were taken into consideration. This choice is based on my first-hand experience and contact with the two online social media pages during the research period.

First of all, I focused on the general topic of the posts shared: through participant observation and direct use of the media, I was able to discover certain repetitive patterns and characteristics in the content shared by Freeda and LOLA. The method I intended to use for the present piece of research consisted firstly on a preliminary study on the subject of gender and advertising. Then I chose to analyse the Facebook publications of the two selected pages, in order to focus on the different media techniques to interact with the audience.

By spending a discreet amount of time as follower of the page Freeda, I was able to recognise a certain pattern in the type of contents shared. In regard to LOLA, I started following it towards its end, meaning that the user experience was different: in the first case I was actively reacting to up-to-date content, while in the second one I found myself digging into old material, basically practising an autopsy of the Facebook page.

Within this study, there was no space or time to analyse all of the posts shared by the two pages. Thus, a selection of the content was implemented. As both pages landed online in the same period of time, around the end of 2016, I was able to consider material from the same time frame, that is to say the period between 2016 and January 2019. In order to analyse the posts with the most interactions, social network data was collected through Facebook app Netvizz and with the aid of the Fanpage Karma analytics online tool, along with the Page transparency option offered by Facebook, which reports the information of the page since its beginning, and the active and inactive ads running on the posts. The posts for the analysis were 
chosen considering the factor of popularity (higher number of reactions, comments and shares) and the topic discussed. 


\section{THEORETICAL FRAMEWORK}

\subsection{CONTEMPORARY FEMINISM: BETWEEN A FOURTH WAVE AND MAINSTREAM FEMINISM}

The western feminist movement has a relatively short but intense and dramatic history. It can be considered one of the most important social movements of the twentieth century, especially after the second half of it. Traditionally, feminist history is divided in three main time periods (Humm, 1990) or waves: the first-wave feminism, developed between the nineteenth and the twentieth century, which saw the fight for the women's right to vote as main protagonist. Later on, the second-wave feminism characterised the years from the 1960s to the 1980s, deepening the debate on gender roles, inequality and women's place in society. One of its most famous slogans was "the personal is political". This debate was in stark contrast with the individual empowerment of the third-wave feminism, which started around the early 1990s in the United States, as both a continuation of the second-wave and a reaction to it (Krolokke and Scott Sorensen, 2005). It lasted until the new millennium, adding to the movement a greater inclusiveness of women of colour compared to the previous periods and advocating for the need of multiple feminisms, as well as starting to be present on the growing platform of the internet. Along these lines, it must be said that the feminist movement has always been a complex set of ideologies and historical moments, as fragmented and different as the women forming part of it. For this reason it is now not uncommon to refer to multiple feminisms, which present differences according to the contexts they are in.

Precisely the context of the internet and its massive use in recent years has sparked the debate on whether we are witnessing the rise of a fourth wave of feminism or not (Munro, 2013). As Chamberlain (2017) explains, there are a number of feminist scholars and journalists who recognise the development of a fourth wave around the year 2012. One of them is Kira Cochrane, who in her 2013's book "All the rebel women" analyses the new rise in activism of the fourth wave, which started in the US but also reached the United Kingdom, on which her research focuses. According to her, the central topics of fourth wave feminism comprise rape culture, online feminism, humour, and intersectionality and inclusion (Chamberlain, 2017). The rising of this renewed feminist awareness and activism would be due to a series of factors, such as a growing concern for body image connected to the diminishing of model sizes; the 
economic crash would also be a reason that sparked a reaction against the austerity in politics. Technology also had without a doubt a primary role in the development of this new moment, as Munro (2013) claims. Social media especially became the site to challenge sexism, to organise feminist campaigns and for people from all around the world to come together and share ideals and fights. It is exactly feminism on social media what this thesis intends to deal with, as Jessica Valenti, founder and editor of the website Feministing.com, reminds us: "maybe the fourth wave is online" (Solomon, 2009)2.

As Andi Zeisler carefully describes in her "We were feminists once” (2016:X), feminism has lately become popular again: "feminism got cool”, she says, quoting celebrities as Beyoncé, Taylor Swift and Emma Watson as the new paladins of the movement; she mentions important brands like Dove, Pantene and Verizon and their sudden feminist approach in their advertising campaigns, and the Paris Fashion Week using feminist slogans in their runways.

What happened so suddenly around the mid-2010s was that "feminism, so long dismissed as the realm of the angry, the cynical, the man-hating, and the off-puttingly hairy, was officially a thing. It was hot. And, perhaps most importantly, it was sellable.” (Zeisler, 2016:XII).

The fourth wave does not only contain social media activists then, but it witnesses the appearance of a type of feminism that can be defined as "marketplace feminism", but also known as "white feminism", "pop feminism", "mainstream feminism", "feel-good feminism". Many names and definitions to describe a kind of feminism that is decontextualized and depoliticised, stripped down of all of its stronger political values in order not to be a threat to the western capitalist power structures. This version of popular feminism becomes "a sticker that anyone and everyone can now apply, largely because it has lost all sense of intellectual rigour or political challenge" (Kiraly and Tyler, 2015:X). Pop feminism has earned its place in the spotlight thanks to celebrities, thanks to movements like \#Metoo, which helped getting necessary attention to the many cases of rape culture in Hollywood, and of course thanks to the internet. Zeisler notes that now it seems not to be a stigma anymore to define oneself as "feminist", now that TV series, magazines, social media and films suddenly swarm with the term. However, it is fundamental to distinguish the mainstream trend that feminism is going through with what the feminist movement actually is. In fact, while the word "feminist" or slogans like "girl power!" stand out on t-shirts and various items of merchandising, while women are always more frequently associated with the concept of "empowerment" on TV

\footnotetext{
${ }^{2}$ Solomon, Deborah. (2009). The Blogger and Author on the Life of Women Online. [online] Nytimes.com. Available at: <https://www.nytimes.com/2009/11/15/magazine/15fob-q4-t.html> [Accessed 15 Sep. 2019]
} 
spots or advertising posters, the issues which are essential to the feminist movement are often irremediably left behind and still under threat by some of the current policies being adopted not only in the Western World, but also worldwide. Just to offer some examples from the West, such policies came to the media attention in the United States with Trump administration $^{3}$ often accused of harming women and families; in Italy with the "parental alienation" proposal ${ }^{4}$, which according to some threaten women who are victims of domestic violence; in Spain with the rising presence of right wing party like Vox, which clearly stands against feminism ${ }^{5}$, and with the many instances of gender violence occurring in the country ${ }^{6}$.

In this dissertation I will make reference to two countries specifically: Italy, because it is my country of origin, where I have lived most of my life; and Spain, because it is the country I am currently living in. When it is said that important feminist issues are menaced by the ongoing situation, it is impossible not to refer to some of the recent events happening in Italy in 2019. For example, in March 2019 the city of Verona hosted the $13^{\text {th }}$ World Congress of Families, which received a series of far-right politicians, pro-life activists and anti-LGBT personalities from all over the world (The Guardian, 2019). In the last years, the rise of a populist right-wing discourse has seen the light, insisting on dictating what a "natural family" should be, and sometimes too often recurring to ways and terminology definitely too close to what fascism was. The far-right drift that not only Italy, but also the majority of Europe is experiencing, is one which justifies racism with the idea that people are tired, hate speech with the concept of being blunt and honest. Finally, it is the one that justifies the desire of control over women's bodies and choices exploiting the religious moral. Similarly, Spain has known a rise of the far right wing with the "Vox", mentioned earlier, a new party whose positions on feminism and women are strongly debatable.

All of these themes are unlikely tackled by pop feminism usually, says Zeisler, as the preferred topics to give attention to are the most media-friendly ones, the fun ones, still focused

\footnotetext{
${ }^{3}$ Frothingham, S. and Phadke, S. (2017). 100 Days, 100 Ways the Trump Administration Is Harming Women and Families - Center for American Progress. [online] Center for American Progress. Available at: https://www.americanprogress.org/issues/women/reports/2017/04/25/430969/100-days-100-ways-trumpadministration-harming-women-families/ [Last Accessed 15 Sep. 2019].

${ }^{4}$ Giuffrida, A. (2018). Italian women's groups fear law change will hurt domestic violence victims. [online] the Guardian. Available at: https://www.theguardian.com/world/2018/sep/19/italian-womens-groups-fear-lawchange-will-hurt-domestic-violence-victims [Last Accessed 15 Sep. 2019].

${ }^{5}$ Beatley, M. (2019). Betting on Anti-feminism as a Winning Political Strategy. [online] The Atlantic. Available at: https://www.theatlantic.com/international/archive/2019/04/spain-vox-feminism/587824/ [Last Accessed 15 Sep. 2019].

${ }^{6}$ EL PAÍS. (2018). Spanish justice system admits it is failing victims of gender violence. [online] Available at: https://elpais.com/elpais/2018/09/28/inenglish/1538128575_682750.html [Last Accessed 15 Sep. 2019].
} 
on heterosexuality and on the idea that to reach equality with men it is indispensable to invite them into the conversation, to better legitimise it (Zeisler, 2016:XIV).

Pop feminism originates from third-wave feminism and liberal feminism, both of which give great importance to individualism, to self-empowerment and to freedom, and it lives inside the fourth wave. It is deeply intertwined with neoliberalism, too, from which derives the term "neoliberal feminism". The focus on individualism promoted by pop feminism is driven by the belief that a certain type of equality has already been reached. It is a position that shares some common ground with the concept of "postfeminism", associated with a type of global neo-liberal discourse (Lazar, 2005:17) very typical in capitalist societies. It supports the concept of "the alleged end of feminism, since it is argued that it is no longer needed" (Mills and Mullany, 2011:10). Along with this idea, comes the liberal belief that women hold their power and their opportunities in their hands. Starting from the 1990s, liberal feminism shifted the liberation of women from a collective action to an individual and private struggle, from resistance and critique to patriarchy to a more individualised model of choice. But, as Kiraly and Tyler (2015) underline, it is there that the root of what they call freedom fallacy lies: if the basis of this freedom and choice rests on inequality and patriarchy, there can be no liberation, but only the illusion of it.

\subsection{DEFINING POP FEMINISM}

In order to define what pop feminism is, it will be necessary to offer an interpretation of three concepts that are deeply connected to it and to which to some extent it stems from. Therefore, this paper will now proceed to explain what the concepts of "pop culture", "postfeminism" and "neoliberal feminism" are.

According to the Collinsdictionary.com (2019), popular culture is defined as "the general culture of a society, including ideas, music, books, and the mass media, as opposed to high culture". Andi Zeisler (2008:1) says that popular culture could refer to any product that has a mass audience. Its use is historically linked to low culture and entertainment for the masses, in contrast with high art, which not only did entertain, but also informed and enriched its consumers. The abbreviation "pop" as in "pop culture" is often used interchangeably with "popular culture", but it appeared in the late 1950s and it is more specific. In an article from LIFE magazine from 1965, Gloria Steinem defined Pop culture as "an umbrella term that covers anything currently in fashion, all or most of whose ingredients are familiar to the public-at-large" (p. 73). Trier-Bieniek and Leavy (2014:12) also define pop culture as the set 
of images, narratives and ideas that can be found in contemporary culture. They add that the popularity of it is due to its general availability to the masses and to the possibility to consume it.

To put it simply, Zeisler (2008) affirms that when we are talking about pop culture we are talking about television, films, radio, magazines and internet, but the discourse is not restricted to that only. Pop culture also comprises "things that were in no way created to entertain us but that nevertheless become part of our mass consciousness" (2008:3), such as historical, social and political events, and pieces of news related to them.

The range of pop culture, therefore, can touch different spheres of people's everyday life, which is the reason it is fundamental to consider it, use it and keep a critical eye on it.

Pop culture shares the "popular" ground with pop feminism, which exploits practices and topics that are available to a wide audience (Banet-Weiser, Gill and Rottenberg, 2019): the specificity of this kind of feminism is to deal with easy matters and themes, issues that can be consumed by users quickly in a context that nowadays possesses characteristics more and more similar to the ones of the market. Zeisler (2014:XII) in fact, associates pop feminism with another successful description, "marketplace feminism". The market or marketplace is the physical or virtual place where goods and services are traded, and where the mechanisms or demand and offer for products take place (BusinessDictionary, 2019): thus, following the market logic, the feminist trend is creating a demand for women's related goods, to which the offer rapidly adjusts. Zeisler explains that the sudden popularity of feminism in recent years, but also the exploitation of feminist themes in advertising to align with the appearance of women as a new target market, transformed the fight for gender equality "from a collective goal to a consumer brand" (2014:XV). It means that pop feminism is partly responsible for the depoliticization and decontextualization of feminism: if brands and media select only certain features of the feminist movement to sell and place products on the market, the loss of meaning of the same feminist movement is inevitable.

But how has feminism stolen the limelight lately? Zeisler (2014) and Banet-Weiser (2019), among many others, ascribe the recent success of it to celebrities and media, as well as the social media platforms on which many topics are nowadays shared, becoming, as a matter of fact, popular. The power of the internet and social media lies on the possibility it offers to keep people constantly connected with each other and up-to-date with whatever piece of information or news they might need. The success and the use of the internet has been rising since the 1990s with the appearance of the world wide web (Ward, 2006) and it has become 
an essential site for people to share ideas and content. Evidently, feminism and women's issues have gained some space online in recent times thanks to feminist activists, writers, artists and content-developers; however, the mainstream fortune that the feminist movement - or rather the word "feminist" - is enjoying these days, comes from the endorsement of such themes by famous actors, singers and politicians (Zeisler, 2014; Farhall, 2015; Banet-Weiser, 2018). A direct consequence of that is that we are now living in a period where feminist discourses have a higher visibility in mainstream commercial media (Banet-Weiser, 2018:2). There are several examples of apparently feminist slogans in advertising aimed at empowering girls and women: just to name a few, the campaigns of Nike, Dove, Verizon and Gillette have all messages that are designed not only to spread positive and feminist themes, but also to gain customer confidence through those same messages and convince the viewers to buy their brand.

Nonetheless, the phenomenon of pop feminism is not new, Banet-Weiser (2018) asserts: it is fundamentally the product of the influence of a neoliberal society and of its derived feminisms, such as postfeminism and neoliberal feminism.

Postfeminism, as briefly introduced before, is a term that made its appearance in the 1990s and that assumed different shades of meaning depending on the context. For this reason, presenting a clear definition of it has been a complex matter since the beginning up until now. Rosalind Gill (2007, 2019) mentions three approaches to the concept: postfeminism has been considered as a historical shift after second wave feminism, as a new kind of feminism in itself, and as a backlash against feminism. Most scholars consider postfeminism negatively, as it seems to imply that feminism is no longer needed: authors like Susan Faludi (1992) argue that postfeminism is a backlash for the movement caused by a conservative response to the achievements of feminism, as it changed the definition of feminism after the second wave and blamed feminism for women's problems in the end of the 1980s. Angela McRobbie (2004, 2009) also suggests that postfeminism takes feminism into account because doing so implies equality has been achieved and feminism has ceased to be useful; when feminism becomes understood as already passed away, she says, then and only then it can be taken into account by postfeminism (2004:255; 2009:12). Despite making feminism look unnecessary, postfeminism accepts it as an evidence of the past, whose values still matter in the present. This combination of postfeminism and neo-conservative values is called by McRobbie (2004, 2009) "double entanglement": freedom, empowerment and choice are given to women in return for feminist politics and transformation (Gill \& Scharff, 2011:4). It can be said that feminism in Western countries is now "part of the cultural field" (Gill, 2007) and it appears 
within the media through TV, radio, computer and print. Still, one must remember that the presence of feminist-inspired ideas inside such media does not mean that they have become feminist all of a sudden. Instead, this circumstance can be explained and associated with neoliberalism.

In A brief history of neoliberalism (2007), David Harvey describes it as "a theory of political economic practices that proposes that human well-being can best be advanced by liberating individual entrepreneurial freedoms and skills within an institutional framework characterized by strong private property rights, free markets and free trade" (p. 2). Similarly to postfeminism, the term neoliberalism is also complex to define; it usually refers to a type of economy, which encourages free markets, reducing the state power, and individualisation. Nevertheless, neoliberalism in never only about economy, but rather is "a dominant political rationality" that constructs and treats individuals as entrepreneurial actors (Rottenberg, 2014:420).

When it interlaces with feminism, neoliberalism "emphasises professional and economic success but not at the expense of the family" (Banet-Weiser, Gill and Rottenberg, 2019), in a newly-found ethic of work-family balance. It was Catherine Rottenberg who coined the term "neoliberal feminism", which is a new form of feminism that acknowledges gender inequality while at the same time ignoring the existence of socio-economic and cultural structures that are present in everyone's life (Banet-Weiser, Gill and Rottenberg, 2019). According to Rottenberg, we are witnessing a rise of neoliberal feminism, and she argues that this new type of mainstream feminism serves neoliberalism's agenda: in fact, it is creating a new feminist subject, who is now individualised and focused on personal choice, one who is ready to accept responsibility for their own well-being and self-care (Rottenberg, 2014; Banet-Weiser, Gill and Rottenberg, 2019). Neoliberalism is therefore hyper-individualist, it does not challenge the power structures or the hegemonic capitalist power relations in which it is inscribed; rather, it assists such structure and aids it to maintain its position. These are characteristics that neoliberalism shares with postfeminism and with third-wave feminism mentality, and that inevitably influences pop feminism, too. As a matter of fact, neoliberal feminism has helped to spread the idea that a woman can "have it all", meaning that her objective should be finding a happy work-family balance; this surely promoted the diffusion of feminism, making it more acceptable and appetising, and therefore encouraging the rise of pop feminism, too.

Since the shift towards individualism and neoliberal values, pop feminism has been targeted by advertisers. The presence of women in advertisement is not new, as it is no news 
the fact that they are the more likely to be objectified, on the assumption that "sex sells" (D'Enbeau, 2011:54), which is a stagnant strategy yet still very much used by media and advertising companies. The change that advertisers were able to take advantage of has been the quick celebrity that mainstream feminism has gained: if sex sells, as mentioned earlier, then even a social movement can. Feminism in the marketplace has become a product to sell, a brand of success to adjust, reshape and customise according to the desires and needs of the buyers.

In marketing, branding is the process responsible for giving a unique and original image to a certain product, in order to advertise it efficiently to a target of customers. The aim of it is to differentiate the product from others on the market, to attract clients and retain them (BusinessDictionary.com, 2019a). Feminism in its popular - or rather populist - form is going through this process: it is being given a new cooler image to get in contact with the widest audience possible. Is it that negative, one may ask? Wasn't the objective of feminism itself to spread to the point of becoming a global movement?

As Zeisler (2016) puts it, marketplace feminism in itself would not be a bad thing, at least in theory; however, when it comes to the practice, "it tends to involve highlighting only the most appealing features of a multifaceted set of movements". In other words, it simplifies the concept of feminism stripping it of all its most complex, political, social and activist values, leaving a colourful, amusing and charming version for the masses.

For this reason, the term pop feminism has been used many times in a derogatory way. For example in "Hatreds: Racialized and Sexualized Conflicts in the $21^{\text {st }}$ Century" (1996), Zillah R. Eisenstein asserts that it "distorts feminism by depoliticizing it". According to her, pop feminism flattens the differences and complexities of the movement, ensuring that it loses the power to fight patriarchy. In her 2017 lecture in Barcelona "Revolution Today", Angela Davis 7 refers to mainstream feminism as "bourgeois feminism", and she accuses it of having made many serious mistakes. Still unfortunately very white, she says, it ignores the huge numbers of academics and women of colour who have changed the essence of feminism and made it the intersectional movement that it is today. Davis affirms that the biggest mistake of mainstream feminism is its continuous reliance of a categorical representation of women;

- $\quad{ }^{7}$ Davis, Angela. (9th October 2017). Revolution today. CCCB: Centre de Cultura Contemporània de Barcelona. Available at: https://www.cccb.org/en/multimedia/videos/angela-davis/227656 [Last accessed: $15^{\text {th }}$ September 2019]. 
moreover, she adds, a feminism that privileges those who already have privilege is bound to be irrelevant to poor women, working class women, women of colour, trans women, and so on.

Again, pop feminism is referred to as a movement that has been made more appetising to the general public by celebrities like Taylor Swift or Emma Watson (Zeisler, 2016). This quick and unexpected embrace of feminism by famous personalities made it popular, but some authors wonder if the goals of the Women's Liberation Movement can come together with mainstream and pop culture. Farhall (2015:97) claims that there are too many "internal inconsistencies in the contemporary liberal feminist movement" for this reconciliation to be possible. The pop feminism approach is in fact based on the idea that equality between men and women can be reached through a positive mindset and a charismatic demeanour, without the urge of modifying the current status quo, cultural institutions and biases.

As was mentioned before, pop feminism and third-wave feminism celebrate the marketplace. Marketing itself is seen as potentially empowering (Maclaran, 2012) now for women. However, Zeisler also remarks that nowadays the term "empowerment" has become gender biased and almost any activity seems to be empowering to women, especially if there is an advertisement behind.

The next section will therefore consider the relationship between gender and advertisement.

\subsection{GENDER AND ADVERTISING: FEMVERTISING}

Advertising is a fundamental pillar of the consumerist society in which we live (Gallego, 2009). Our society is sufficiently developed and commercialised to allow the presence of certain strategies that can sell goods and services; along with these strategies, a percentage of people in the Western world possesses a degree of comfort that permits it to have room of movement in the choice of a number of products. These products therefore compete in catching the attention of customers, which differs according to the gender of the subjects, according to Sheehan (2013:89): advertisers have always seen men and women as different and reproduced them as a consequence of these differences and stereotypes; however, men and women also approach advertising with distinct perspectives. Since the 1950s, gender roles have changed and shifted, and with them also their representation in advertisements.

Considering that advertisements are meant to stick to the viewers' mind, it is clear that they strongly rely on the visual impact and on the constant repetition of tropes; when it comes to gender differences, these tropes are declined in stereotypical characteristics attributed to men and women. 
Thus, gender and advertising share a strong and deeply intertwined relationship: the marketplace requires products to be sold to a certain target and advertisers have the task of attracting this target towards the product. Hence, because of time and space limitations, the easiest and most effective way to engage and create a relation with the customers is to use stereotypes. In fact, as Sheehan (2013) explains, using gendered stereotypes is effective because it helps setting the scene immediately, allowing the advert to focus on other type of information about the products or services shown. Gender identity is in fact reinforced by traditional advertisements: male characteristics are usually connected to knowledge, courage, strength and dynamism; on the contrary, female traits have to deal with beauty, youth, seduction, erotism, pleasure, sensuality and passivity, just to mention some of the most common ones (Gallego, 2009). Up until the present times, gender roles in advertising have hardly be challenged. The classic 1950s formula that presents women as homemakers and men as breadwinners still lingers in nowadays' advertisements. However, there have been attempts at changing the language in which a selling message is being delivered to potential customers. Zeisler (2016:16) reports the example of the Mattel brand, owner of the Barbie doll, which in 1999 went through an advertising campaign that aimed to be empowering for little girls - and also erase a faux pas made with an early talking doll which caused some controversy. One of the doll's sentences, in fact, repeated how difficult Maths was, risking to condition little girls and "making them lose confidence in their math ability", as The American Association of University Women denounced (in Zeisler, 2016:16).

As a result, in an attempt to clear their image, Mattel issued posters reciting "Girls Rule" and "Become Your Own Hero", straying greatly from the image that the doll had been giving since its creation in the 1960s. Positive messages like these express a shift in the marketing strategy of a company and they might be interpreted as a great change; nonetheless, as Edut (1999:16) comments, “Ads telling girls they can 'be anything' or 'become their own hero' are only wrapping the Mattel message - buy our products now! - in a vaguely girl-positive package." Girl positivity and empowerment are two of the recurring terms that appear in popular/populist feminism, which lead this dissertation to explore and define a phenomenon extremely modern nowadays: "femvertising". As this research intends to examine examples of pop feminism on social media, it is necessary to engage with said phenomenon, since it will be shown there is a relevant connection between the two.

The term "femvertising" comes from the \#Femvertising Awards created in 2014 by Samantha Skey, Chief Executive Officer at lifestyle site SHE Media. In October 2014 the site 
hosted an Advertising Week panel to "celebrate brands whose advertising defies gender stereotypes"; resulting from the union of "feminist" and "advertising", it is described as a type of advertising that uses pro-female talent, message and imagery to empower women and girls (Corporate.shemedia.com, 2019).

A study by Åkestam, Rosengren and Dahlen (2017) refers to it as a category of contemporary advertising that questions traditional female gender stereotypes that were in part originated by advertising itself. It is said to be, to some extent, a challenge to traditional advertising, as it interrupts the stream of clichéd female representation (Eisend, 2010). Both the aforementioned study and SHE media company assert that Femvertising is actually changing the behaviour of female customers when purchasing products. SheKnows Media conducted a survey in 2014 , which confirmed that $52 \%$ of the women who responded claimed to have bought a product especially for the way women appeared in its advertisement; the $91 \%$ of women interviewed agree with the idea that the portrayal of women in advertising has got a meaningful impact on girls (Corporate.shemedia.com, 2019). Åkestam, Rosengren and Dahlen (2017) also prove that femvertising is perceived by the viewers to be less stereotypical than the traditional advertising: this implies a more positive approach to the advert, an increase of possibilities to relate to the target of customers, and a reduction of the so-called "advertising reactance", that is to say the unpleasant feeling people go through and that follows a threat to lose their freedom.

Since 2014, examples of femvertising campaigns came from a number of big brands such as Dove, Always, Verizon, Google, and Chevrolet (Davidson, 2015), whereas to mention a more recent viral advertisement, it is necessary to refer to Gillette's 2019 campaign "The Best Men Can Be". All of these cases of feminist advertising play with the viewers' emotions and with specific words frequently related to the concept of empowerment. The strength of pop feminism and consequently of this kind of advertising relies exactly on the belief that every woman has the ability of choosing by herself; Zeisler (2016) coined the term "empowertising" to refer to the practice of mildly talking about feminism with the scope of inciting product consumption. Yet, the alleged power that derives from this consumption is an illusion, as Angela McRobbie $(1997,2007)$ claims: the sense of power that comes from the act of consuming commodities has nothing to do with feminism, and the language of empowerment used in the marketplace should not be confused with the feminist movement (D'Enbeau, 2011). 
However, as mentioned earlier on, pop feminism has lately been experiencing a new rise in popularity especially online, and the world of the internet has also become another favourite place for advertisement. Thus, the fortunate spread of mainstream feminism on social media could not go but hand in hand with advertisement. This dissertation intends to argue that the relation between feminism, social media and advertising inevitably influences the type of language and tone chosen to express their content. For this reason, the following section will describe two examples of pop feminist pages on social media. Consequently, examples of their posts will be presented and considered. 


\section{ANALYSIS \\ 2.1 FREEDA MEDIA AND BUZZFEED LOLA}

Freeda Media is an Italian start-up and media brand which is active on social media platforms such as Facebook, Instagram and YouTube. As described on their LinkedIn profile, they are

"[...] the \#1 media brand for entire generations of women. Inspire, represent and speak to them is what we care most, through unique content and experiences that we are passionate about. Our mission is to spread real women's stories to inspire positive change and impact society at large. We do that by promoting women's achievements, inspiring personal style and celebrating sisterhood. We create original premium content designed for all screens and social platforms dedicated to the relevant passions, cultures and news to young women. Our team is composed of over 150 people, spread around Italy and Spain, who create content and share experiences dedicated to a community of $+4 m$ women every day. Nevertheless, we continue to invest in our team - planning unique content, original and meaningful collaborations, and expanding to new countries."

Since its founding in November 2016, it has known a progressive growth in followers, reaching in May 20191.6 million likes on the Italian Facebook page, 1.1 million on the Italian Instagram profile, and counting 75.133 subscribers on their YouTube channel. As of October 2018, the company also landed in Spain after receiving a 10 million dollars financing (https://ipmark.com/Freeda-llega-a-espana/). The Facebook page appeared online on $28^{\text {th }}$ of October 2016; the core of this multimedia platform's activity takes place on social media, while the website www.Freedamedia.com only features links to the Facebook and Instagram profiles, a brief presentation of the employees in colourful, pop art style drawings, and a display of real time followers growth, people reached, video views and interactions. The fruition of blog posts which are shared daily on the social profiles is linked to a Wordpress page, whose dominion is <Freedamedia.it>, but there is not a physical blog to access. Everything, from articles, to pictures, to videos is accessible through social media. It is the instant content typical of other brands, such as AJ+, Buzzfeed, Vice, other examples of news and entertainment companies which are present on Facebook; they offer their users short videos and articles that anyone can quickly come in contact with on their feed. 
The name "Freeda" traces the word "freedom" and at the same time it resembles phonetically the name "Frida", recalling the painter Frida Kahlo, who has become a symbol of female independence (DINAMOpress, 2017; Facebook.com, 2019).

As the editor in chief Daria Bernardoni explained in the 2017 Conference of Young Entrepreneurs of Confindustria (https://www.youtube.com/watch?v=y4-NQ9BK_YQ), Freeda was born as the first new generation media to target millennial women in Italy. With just four months of content publishing, they were able to obtain 570.000 fans, $90 \%$ of which are women between 18 and 34 years old. Thanks to shares, comments and likes, Freeda was able to reach an impressive audience of 17 million people. Claiming to be the "voice of a new generation of women", their target focuses on young female users of social media, which have now substituted television as a source of information and entertainment. Freeda is described as a generalist editor, therefore dealing with a wide range of topics, mainly focusing on stories of women who "broke barriers and improved the society thanks to their strength" (https://www.youtube.com/watch?v=y4-NQ9BK_YQ). The type of content used to tell these stories appears in the form of videos, usually short, colourful, with catchy music and subtitles in order to be seen even without the audio on. According to Bernardoni, video is the natural language of this generation, who wants to get informed and have fun, while still being able to contribute positively to the change. The approach of the brand is data driven, meaning that the users and audience's feedback plays an important role in the development of new content. The editorial proposal is shaped on what fans seem to appreciate more.

It is then in this regard that the seemingly feminist start-up reveals its other aim: a business project intended to offer to firms and companies the opportunity of entering in direct contact with this target through activities of marketing and communication; in the words of Bernardoni, any brand who would want to start a conversation with women between 18 and 34 years old could do that only through Freeda, which is already the motor of their exchanges.

Another generalist editor is the American internet media and entertainment company Buzzfeed. Based in New York City, it has got branches internationally, including among the others London, Paris, Berlin, Sydney, Tokyo, Ciudad de Mexico and Madrid. The latter hosted Buzzfeed España for a period of time going from the $29^{\text {th }}$ June 2015 until the $26^{\text {th }}$ January 2019, when the section was permanently shut down following a series of staff cuts which affected the company internationally. The Spanish section of the company also had another portal, Buzzfeed LOLA, also known as LOLA, which appeared online on the $24^{\text {th }}$ August 2016. It was explicitly dedicated to feminist and equality issues, self-described on its Facebook page 
as "feminismo pop de la mano de Buzzfeed España", pop feminism hand in hand with Buzzfeed Spain.

Similarly to Freeda media, LOLA was also active on social media: its main platforms were Facebook, Twitter, YouTube and Instagram, where it shared images and memes, videos and articles linked to their website, www.buzzfeed.com, associated to the American one.

The analysis that this dissertation intends to carry out focuses on the types of format which the two social media pages use, and on the language inscribed in them. The aim is to delineate the style with which online pop feminism treats its main topics and themes. Moreover, considering that the two selected pages come from different countries such as Italy and Spain, what was expected to encounter are peculiar characteristics for each of them. The contents considered consist of selected videos, photos and instant articles published by Freeda Media and LOLA between 2016 and 2019.

The following sections will firstly examine Freeda's posts, and later on LOLA's ones, introducing three of the most representative samples for each type of media shared.

\subsection{FREEDA: ANALYSIS OF THE LANGUAGE}

As previously mentioned, the main format that Freeda uses to engage with its followers is video. It is said to be the natural language of the millennial generation (Giovani Imprenditori Confindustria, 2017), and it is the easiest way to capture the short attention span of social media consumers. The duration of these videos swings between one and four minutes approximately; they appear to be colourful, sometimes in the style of an interview, other times in the style of brief documentaries. Freeda groups its videos in many diverse formats with several chapters, and they range from frivolous series to slightly more serious ones. Just to present some examples, on the Facebook page one can find "Cosa c'è nella tua borsa", "What's in your purse", in which girls show what they carry with them daily; another one called "Girls chatting", which is made of very brief videos telling the everyday adventures of a Whatsapp group of girlfriends; to "Speech", which gathers celebrities, actresses and writers' talks edited and subtitled, usually expressing some empowering and feminist topic. But there are also videos focused on women who made history and short documentaries.

Another kind of popular content offered by Freeda are the colourful photos shared every day on their page. They usually present a short sentence or quote from pop culture, such as films, tv series or actors and actresses; alternatively, the images intend to be funny memes - an internet concept for ideas, usually humorous, that spread rapidly among users. Along with the 
writing, the pictures are always in the form of a drawing; they range from the typical empowering messages directed to girls, to representation of everyday cliché "girly" situations, mostly related to make-up, friends and food.

Lastly, the Facebook page offers instant articles about various themes and topics, related once again to popular culture such as characters from series and films, to famous women of the past or of the present and their lives, to sex education articles. It resembles in substance any magazine addressed to a young female audience. Some of the posts, pictures and videos on Facebook are accompanied by an advertisement, called paid partnership. According to the explanation given by Facebook, a paid partnership post (also known as branded content) uses a label to tag the business partner in the content. The Paid label is applied to the post in the meta data.

In the analysis of the language this detail will be taken into consideration, because it is interesting to notice how the stories Freeda decides to tell are connected to the brands which appear in their contents.

\subsubsection{VIDEOS}

The first video considered was posted on May, $23^{\text {rd }} 2019$, and it belongs to the series entitled "Freeda for the record", which encounters women from different fields and through short interviews tells their stories, their jobs or their activities. The subject interviewed was Francesca Vecchioni, a civil rights activist, expert in communication and journalist, who in less than three minutes explains the aim of her association "Diversity", a no-profit organisation that works against discrimination for the sexual orientation, religion, ethnicity, and that fights for inclusion. The theme is particularly relevant and current, and it is somehow refreshing to see such content on a platform that is able to reach a vast number of users.

However, Italian pop feminism in the style of Freeda is still impregnated with some sort of mentality - typically Italian, from what I can personally tell from my experience - that, while telling women to be empowered, tries to maintain them inside the status quo.

Vecchioni opens the video presenting herself:

"Sono Francesca Vecchioni, presidente di Diversity, attivista e mamma".

${ }^{8}$ Freeda, $23^{\text {rd }}$ May 2019. Freeda for the Record: Francesca Vecchioni. Available at https://www.facebook.com/freedamedia/videos/vl.257611188228968/684605065282009/?type=1 [Last Accessed: $15^{\text {th }}$ September 2019]. 
“I'm Francesca Vecchioni, president of Diversity, activist and mum".

It is striking to notice that next to her job titles the role of "mum" appears, showing indirectly how a woman can "make it", trying to improve things and still create a family. This type of communication is very emblematic of Freeda, which usually tends to highlight experiences of women who were able to get success in their area of expertise or environment all by themselves, highlighting a sharp individualism.

Another example that was observed was the video titled "Freeda's game changers: Virginia Cancellieri"”. With 513 thousand of views, 2.2 thousand reactions and 247 shares on the $10^{\text {th }}$ June 2019 , it describes the experience of Virginia Cancellieri, a young road racing cyclist from Italy. It is sponsored by Volkswagen, as it appears next to the name of Freeda's page with the "paid partnership" label. The video shows the woman during her mountain-bike activity and telling things about herself and her sport; she talks about goals and objectives, about the freedom and the independence that her passion gives her. She is portrayed not only in her sport moments, but as well sitting as if she was being interviewed and driving a Volkswagen Up!, too. The image of a young, talented woman is clearly supposed to inspire the viewers to achieve their life goals, but also to focus on the Volkswagen Up! car that is being advertised between a frame and the other. In the video, Virginia Cancellieri says:

"Per me la massima libertà è partire da casa con la mia macchina e fare cinque, sei ore di viaggio per raggiungere un evento, una gara, salire in sella alla mia bici e sentirmi completamente indipendente"

"For me, the biggest freedom is leaving home with my car and driving for five, six hours to reach an event, a competition, getting on my bike and feeling completely independent"

The feeling of freedom and independence described is directly associated with the Volkswagen brand and symbol. When she describes her path, she remembers the moments in which everything was going well, until an accident resulted in her breaking a hand. She then had to slow down, she tells the viewers:

"All'ennesima brutta caduta, il mio corpo ha deciso di frenare per me"

\footnotetext{
${ }^{9}$ Freeda, $29^{\text {th }}$ May 2019. Available at : https://www.facebook.com/freedamedia/videos/328107454531596/. [Last Accessed: $15^{\text {th }}$ September 2019].
} 
"At the umpteenth fall, my body decided to brake for me"

The word "brake" and the video of the car she is driving overlap smoothly, right in the moment when the car brakes by itself inches before hitting another car on the road. Words and images are synchronised just as in an advertisement in order to highlight the parts and functions of the car. Therefore, what becomes obvious is that the empowering story of Virginia is the pretext and the opportunity to connect pop feminist concepts with a marketing move. Exploiting the presence of women is nothing new in the advertising world: as Zeisler (2016) explains, there have been several campaigns which used the ideas of freedom and emancipation to take advantage of the $20^{\text {th }}$ century women's movements and capitalise on them.

The third video considered comes from a series of brief interviews to women, called "Woman crush on", and the title is "Woman Crush On: La Bigotta"10, which was posted on the $7^{\text {th }}$ August 2018 (Freeda Media,2018). Among the one hundred and ten videos of the series, it is the one with the most views (6 million), 1856 shares, 11 thousand reactions and 534 comments. Anna Neudecker, also known as her stage name La Bigotta, is a tattoo artist and in little more than three minutes she tells the story of how she became one. The camera lingers on her tattoos, which cover all of her body, while she explains how her appearance was uncommon and difficult to accept for some; nevertheless, despite the struggles she said to have endured, she was able to establish herself as a tattoo artist. It is yet another story of empowerment and of "self-made woman" that follows Freeda's mission of revealing women's narratives.

\footnotetext{
${ }^{10}$ Freeda, $12^{\text {th }}$ September 2017. Available at: https://www.facebook.com/freedamedia/videos/1842563179388332/. [Last Accessed: 15 ${ }^{\text {th }}$ September 2019].
} 


\subsubsection{PHOTOS}

Examining the pictures shared by the Facebook and Instagram profiles of Freeda, the first detail that attracts attention is the presence of colour (figure 1): almost all the photos are in the form of a comic, usually accompanied by short slogans and sometimes by a detail of the product they are advertising (figure 2).

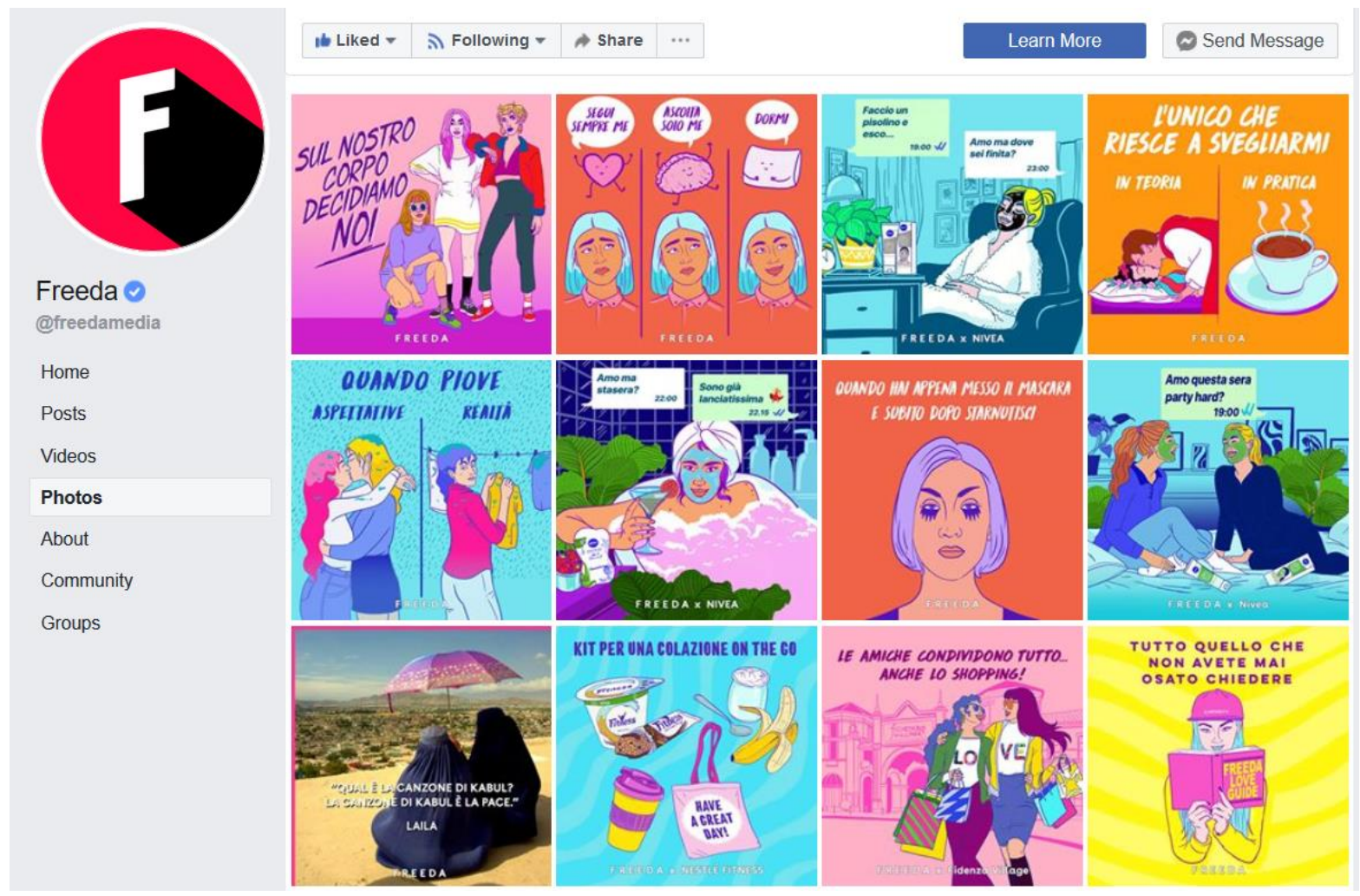

Figure 1 - Photos feed of Freeda, 01.06.2019 


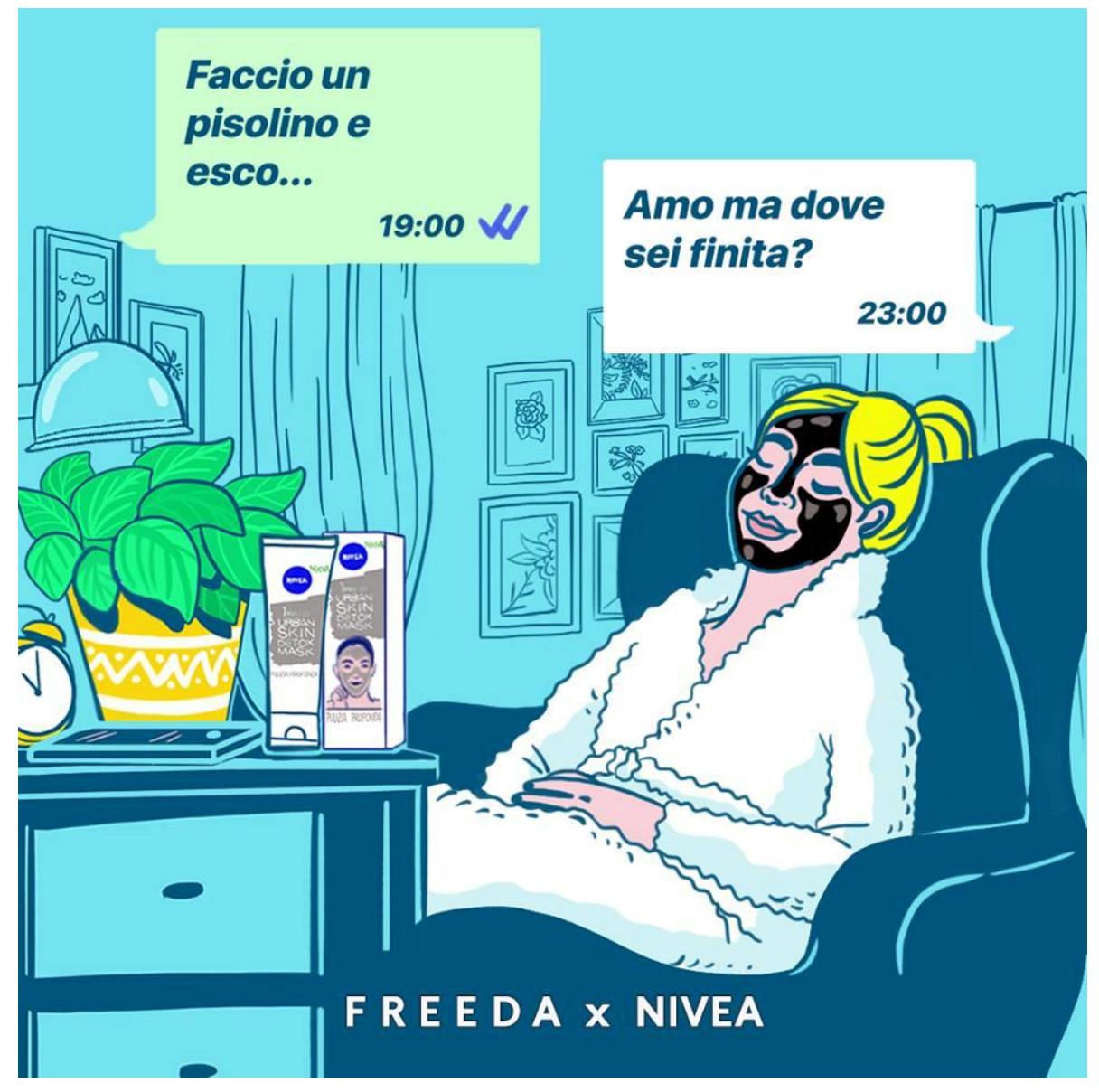

Figure 2 was posted on May $24^{\text {th }} 2019$ on Facebook with the caption "Il venerdì sera ideale", "The ideal Friday night", along with the hashtags \#NIVEASwitchOffClub and \#MaskOnSwitchOff. NIVEA sponsors the content, which shows a girl in a bathrobe relaxing at home with a face mask. Next to her a NIVEA cream tube is shown. On the top of the picture there are two cartoon bubbles that represent a Whatsapp

Figure 2 - Freeda's Advertisement

conversation between two friends. The first one says at 7 PM: "Faccio un pisolino e esco...", "I'll take a nap and I'll come out..."; at 11 PM the answer arrives: "Amo ma dove sei finita?", "Sweetie, where are you?". In this brief exchange, the use of slang words in the text messages is expressing the attempt at representing a generation that is used to talking through the phone, and consequently attempting at relating to them, at a level which can gain their trust. Finally, on the bottom of the image, the writing "Freeda x Nivea" appears.

The humour lays upon the fact that the young girl represented has preferred staying at home enjoying her alone time rather than go out partying. This type of humour is very common among young people nowadays, and especially to the target of Freeda media. By winking at its users with this kind of content, Freeda is able to place products like NIVEA's. The term used in marketing for this practice is native advertising. It is a form of internet advertising that, in order to spark interests in online users, imitates the aspect and the form of the contents of the site where it is hosted. The objective of this is to reproduce the user experience of the context in which it is positioned, both in aspect and content. The advertisements on Freeda 
follow this type of practice and it helps connecting with their users and consumers, because it offers relevant information in a way that is not so intrusive.

In the case of Figure 2, the brand name does not distract the user from the funny picture and caption, yet the image subtly reinforces the message that the brand wants to give: our products can keep you company when you decide to dedicate some time, rest and care to yourself.

Another emblematic image that is shared on Freeda's Facebook page is the one which represents a quote from a celebrity, usually meant to be inspiring, uplifting and of course empowering. The following picture was posted on August $3^{\text {rd }} 2018$ and it displays Emma Watson along with a sentence that recites:

"Alle ragazze viene insegnato di essere delle principesse. Hermione insegna che possono essere delle guerriere."

"Young girls are told you have to be the delicate princess. Hermione taught them that you can be the warrior."

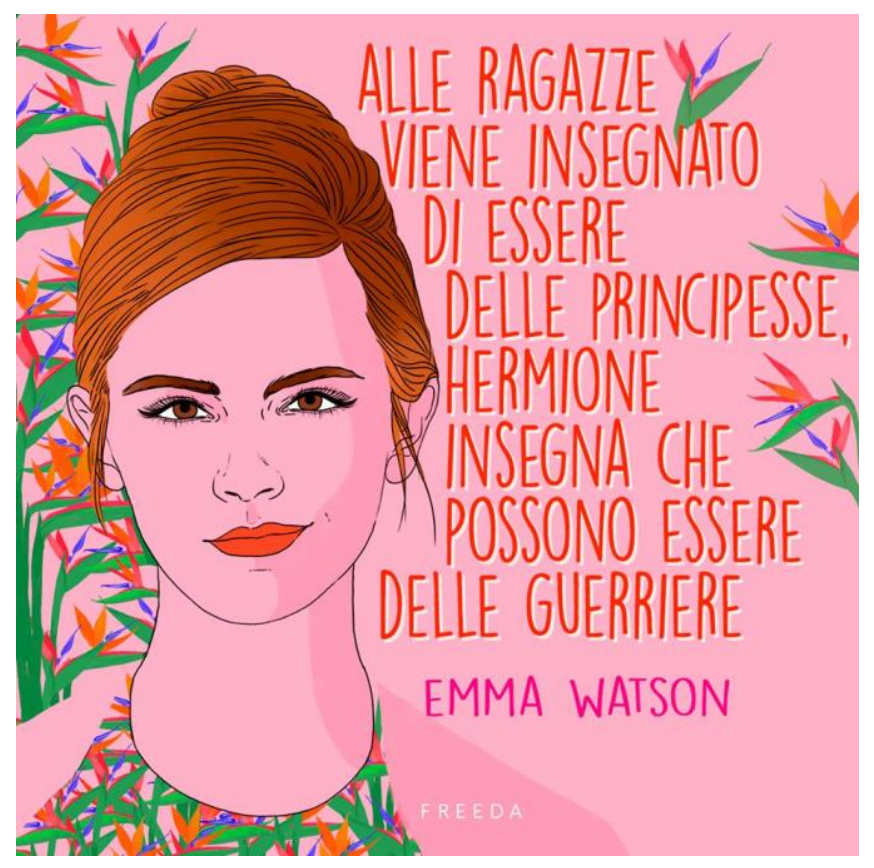

Figure 3 - Freeda, August 3rd August 2018

The image and the text share the same amount of space on a pink background. Emma Watson is an actress and since 2014 a UN Women Goodwill ambassador; the speech she gave to the United Nations in November 2014 for the initiative HeForShe - a movement for gender equality - made her an "overnight sensation" (Zeisler, 2014) and she became one of the main faces and representatives of mainstream feminism. It is considerably common to encounter feminist content related to her online, and on Freeda's page it is possible to count more than ten posts dedicated to her, between videos, photos and articles. 


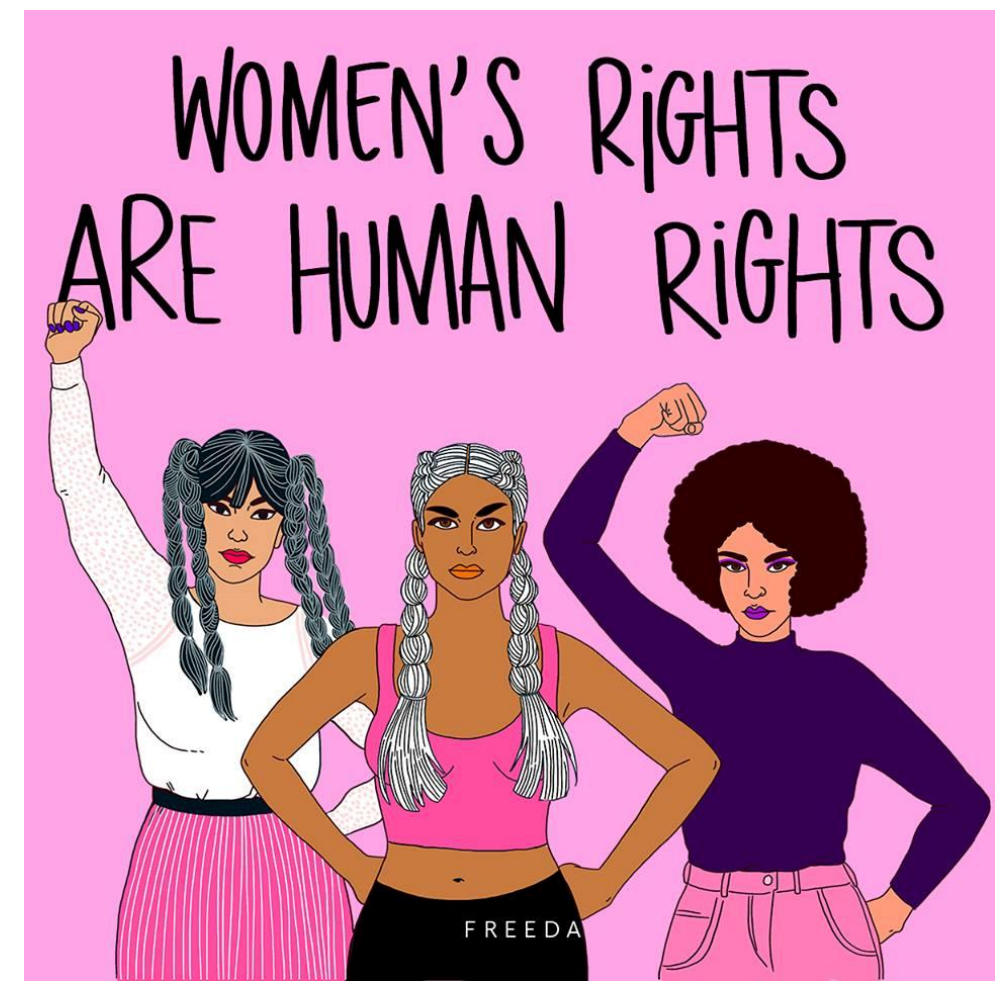

Figure 4 - Freeda, December 2nd 2017

Finally, after considering one branded photo and a one depicting a celebrity quote, the third picture was chosen among the ones showing a classic feminist slogan.

The post reached 2.3 thousand reactions, 165 shares and 45 comments. It shows three girls on a pink background and under the slogan "Women's rights are human rights". The girls look adamant and fierce, and they are portrayed as slightly diverse, as some details suggest: the afro hair of the right one, the olive-coloured skin of the central one, and the barely almondshaped eyes of the left one. The choice of the motto is not original, but reflects a most common sentence used by feminists in many occasions, especially since the 1980s and 1990s (Fester, 1994).

The photo in question represents the pop feminist soul of the page to the fullest: after advertising creams and shops, after preaching about self-esteem and self-confidence in a hasty manner and quoting the celebrity of the week, Freeda reminds its followers of its - literally pink-washed feminism.

\subsubsection{ARTICLES}

The last part of the analysis will concern three of the instant articles shared by Freeda on its Facebook page. Compared to the visual contents, the articles display way less interactions and shares, which proves the theory that social media users prefer fast, immediate content to enjoy, and even a three minute reading could result tedious. The following graph (figure 5) was created with the website Fanpagekarma.com; it shows the different types of posts shared between the $29^{\text {th }}$ of November 2016 up until the $29^{\text {th }}$ of January 2019. The clear majority of video content (in green) outnumbers the amount of link content (in yellow), which refers to the instant articles shared. 


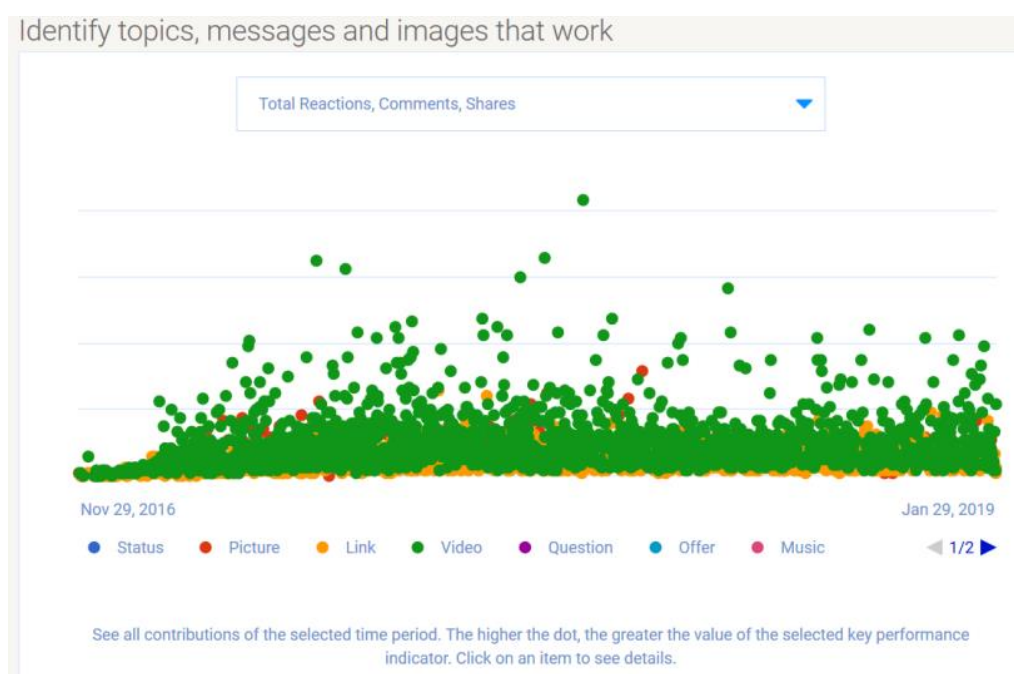

Figure 5: fanpagekarma.com, Total reactions, Comments and Shares of Freeda's posts between 29th November 2016 and 29th January 2019

Each article selected was the most popular in a specific time period, according to the analysis of website fanpagekarma.com.

In the interval between the creation of the page and the following year, the most clicked article resulted to be "Non è del tutto vero che non andremo ai mondiali" ("It is not entirely true we're not going to the World Cup"). It was posted on November $16^{\text {th }} 2017$, it reached 4.9 thousand of shares, 470 comments and 23 thousand of reactions. The topic was sport and the article covered the news that Italy Women's National Football team was still competing to qualify for the Women's World Cup, while all the attention was focused on the men's team, which could not pass the qualifications. The article is brief and simple, followed by a couple of photos of the women's team.

The second article was the most clicked between the year 2017 and 2018; titled "Essere Fantaghirò" ("Being Fantaghirò"), it was shared for the first time on Facebook on December 2017 , but it obtained more success the second time it was posted, on December $4^{\text {th }} 2018$, with 3.9 thousand of shares, 14 thousand reactions and 1.1 thousand comments. The subject of the article was a piece of Italian pop culture from the 1990s, the successful TV series "Fantaghirò". The author makes a sort of review of the series, talking about the female protagonist and of her important role as a character that defied gender stereotypes in a time where very few other fictional characters did in the Italian panorama. The tone of the article is very ironic, and there are comments about the handsomeness of some of the male actors. 
The third article was posted on May $29^{\text {th }} 2019$, and it was the most clicked between November 2018 and May 2019, with 2.1 thousand of shares, 14 thousand reactions and 515 comments. The title recites "Se entra in vigore la legge sull'aborto, Netflix lascia la Georgia" ("If the abortion law is approved, Netflix will leave Georgia") and it deals with a fact of the current news, that is to say the abortion right that was being discussed in the United States. The article is short, but explains how celebrities and big entertainment companies such as Netflix are reacting to the abortion laws in the USA and in particular in the state of Georgia, where many series are shoot; Georgia specifically is among those States, which want to limit the possibility to abort to the very first weeks of pregnancy, mining the agency of women. If the restrictive laws about abortion will become effective, actors and Netflix promised to rethink the agreements and the economical investments made in that State, and to potentially withdraw them.

\subsection{LOLA: ANALYSIS OF THE LANGUAGE}

For the analysis of the Facebook page of LOLA, a selection of videos, photos and articles shared was considered. Firstly, it is important to consider that the style of the page follows the Buzzfeed one, the main website it stemmed from. Buzzfeed normally relies on short, catchy and funny videos, not necessarily educative; alongside with this, it uses images and memes, sometimes accompanied by jokes in the description; in addition, articles from their website are shared directly on the Facebook page. Buzzfeed is mostly known for its tests and typical "listicles", a very common way of writing articles on the web: as the name suggests, the article is based on a list structure, which allows a rapid production and many times not so original content. LOLA, for its period of time online, followed partly this structure, sharing content in English from the Buzzfeed US production and adding subtitles in Spanish. As time passed, the editorial staff also started creating their own original contents, such as video interviews, images and articles.

\subsubsection{VIDEOS}

The videos considered were chosen by popularity, topic and form, in order to have a variety of typologies and to be compared to Freeda's ones. 
The most viewed and reacted video was one titled "«Es que las gordas...” Por favor, CÁLLATE.»", "«But the fatties...» Please, shut up"11.

It was posted on $26^{\text {th }}$ January 2017, it reached 21 million views, more than 531 thousand shares, 85 thousand reactions, and more than 5 thousand comments. It only lasts 49 seconds, and it shows a series of photos of overweight women while smiling and in beautiful poses, followed by a background music and remarks in big characters against a coloured screen; the aim is to tackle the stigma and the prejudices around non-normative, fat bodies, which usually assert that being fat is an issue, a physical risk and overall ugly. The video responds to these typical comments with pictures representing overweight women as happy, pretty and empowered, in control of their bodies; then, it just addresses the viewers and those who criticise, and it elicits them to "Stop saying nonsense, a size does not limit you".

Another video which had a discreet success was one titled "La virginidad es una mentira", "Virginity is a lie" . It was posted on $12^{\text {th }}$ March 2018, it reached 3.5 million views, 61 thousand shares, 68 thousand reactions and almost 6 thousand comments. The length of the video is three minutes and concerns the beliefs around female virginity and the hymen. Its structure is simple: Beatriz Serrano, editor at Buzzfeed LOLA, explains and debunks myths to the viewers in an easy way, yet maintaining the ironic, sarcastic tone with brief GIFS or funny pictures that appear during the talk. The sources of the topic she is explaining appear on the top corner of the video, giving the audience the chance to verify the information and making the video more educational than amusing.

The words chosen to explain the subject are straightforward, understandable and not too much scientific: terms like "vagina", "hymen", "penetrative sex" - which for a long time have been surrounded by some taboo aura - are used normally; however, the explanations do not get lost in technicalities, but remain in the realm of pop culture, with references to TV series, even. This might be due to the desire of connecting with a large target audience, made of young girls and older ones, with different degrees of education and knowledge on the matter of virginity. The following transcription is taken from minute 0.05 to minute 0.40 of said video, in order to show the words used and how the jokes and breaks are inserted in the speech.

\footnotetext{
${ }^{11}$ LOLA, 26 ${ }^{\text {th }}$ January 2017. Available at

<https://www.facebook.com/buzzfeedlola/videos/1708894429400451/>. [Last Accessed: $15^{\text {th }}$ September 2019].

${ }^{12}$ LOLA, $12^{\text {th }}$ March 2018. Available at:

<https://www.facebook.com/buzzfeedlola/videos/1900811553542070/>. [Last Accessed: 15 ${ }^{\text {th }}$ September 2019].
} 
"Seguramente desde pequeñita has imaginado que el himen es una especie de capa que hay a la entrada de tu vagina y que se rompe o explota cuando pierdes la virginidad. [GIF of nuclear explosion captioned: "Well no, that's not what happens to your hymen"] Y que por eso es normal sangrar la primera vez que practicas sexo con penetración: porque algo se ha roto. [Short video clip from the film "The Shining", where the corridor is flooded with blood] O que si no sangras es porque tu himen ya se rompió alguna vez cuando montabas en bicicleta - o montabas a caballo si eras una de las protagonistas de Downtown Abbey [GIF of actress Maggie Smith in the series Downtown Abbey]."

"Surely since you were a girl you've imagine that the hymen was some sort of layer at the entrance of your vagina, that breaks or explodes once you lose your virginity. And that because of that, it is normal to bleed the first time you have penetrative sex: because something broke. Or that if you don't bleed it is because your hymen already broke when you mounted on your bike - or on your horse if you were one of the protagonists of

Downtown Abbey."

In just thirty-five seconds of explanation, the video includes three references to popular culture. It is not unusual to encounter this type of content online, and it is clear that - along with the short duration of these videos - the motive is connected to the short attention span and desire of distraction and entertainment of the users. Therefore, to convey an educational video, it seems to be necessary to wrap it with frills that can keep the eyes glued to the screen.

The third video that was taken into consideration came from a series called "Girl Crush". As Freeda also has a series of videos with an analogous title, it was interesting to consider an example of both to compare them later on in the results section. The video in question was titled "Girl Crush: Teresa Rodríguez"13, and it was selected for this analysis because it had 72 thousand views, the highest number among the other videos of the series; what is more, it is the longest interview with its 19.10 minutes, and the protagonist of the video is Teresa Rodríguez, politician and member of Spanish left-wing party Podemos. The video was posted on $22^{\text {nd }}$ November 2018, it reached 508 shares, and it counts 535 reactions and 18 comments.

${ }^{13}$ LOLA, $22^{\text {nd }}$ November 2018. Available at: <https://www.facebook.com/buzzfeedlola/videos/1075878212579673/>. [Last Accessed: 15 ${ }^{\text {th }}$ September 2019]. 
The interview presents its questions on screen next to the interviewee, who is given space to articulate her answers about politics, the feminist movement and male chauvinism situations she had to experience; she does not only talk about her own perspective, but she includes different points of view in her discourse, without focusing on the merits or the chances she had to arrive where she is. She says:

"Hay que preocuparse del techo de cristal pero también del suelo pegajoso, que se habla en termino feministas."

"It's necessary to deal with the glass ceiling, but also with the sticky floor, how they say in feminist terms"

The quote mirrors what Angela Davis said in her speech in Barcelona in 2017, referring to the mainstream feminism as "glass-ceiling feminism", which is grounded in hierarchy, as the ones who can break the so called glass ceiling are those who already have the privilege, while the ones who still are bounded to the ground are somehow left behind by the popular rhetoric.

\subsubsection{PHOTOS}

Similarly to Freeda, the pictures shared by LOLA are usually funny and ironic; they appear in the form of quotes by celebrities, of screenshots from Twitter or Instagram's users, or of memes always related to feminism. The Facebook timeline of the page presented a total of 684 images, and the three most popular ones according to the app Netvizz were considered. The photos which collect the most reactions from users and fans are mostly jokes or funny quotes.

The first one shows a quote taken from an Instagram account, which appears on the bottom Solo tenemos dos certezas en esta vida:

1. la muerte

2. y que si te acuestas con una camiseta de tirantes al día siguiente te despertarás con una teta fuera

vía IG vodkalana part of the image. The text recites: 
"In this life we only have two certainties:

\section{Death}

2. If you go to sleep with a vest, the next day you'll wake up with one tit outside"

The example in Figure 6 represents distinctly the type of humorous content that the page shared. It can be said that it targets people who identify as women and the aim is to report a common everyday experience which is shared by the majority, hence the great success of the post in terms of users' feedback: it reached eleven thousand reactions, thirty-seven thousand shares and one thousand five hundred comments. The style of the image is very common to find online and it engages with the followers through humour. It is interesting to notice that the most reacted picture of the page is not focused on a feminist topic: rather, it involves the users in a conversation about the only two secure things in life. It contrasts an ordinary yet amusing experience (the fact that sleeping in a vest usually implies waking up with one breast outside), with the inevitable question of death, creating a fun response in the readers. As it was said in the beginning, pop feminism does not want to be too serious. In the words of LOLA's editor, the creation of the page came from the desire of sharing feminist content with people, as Spain was lacking this type of material at the time. Thus, the decision of creating a page whose objective was to be "feminism for beginners" (Medium, 2019).

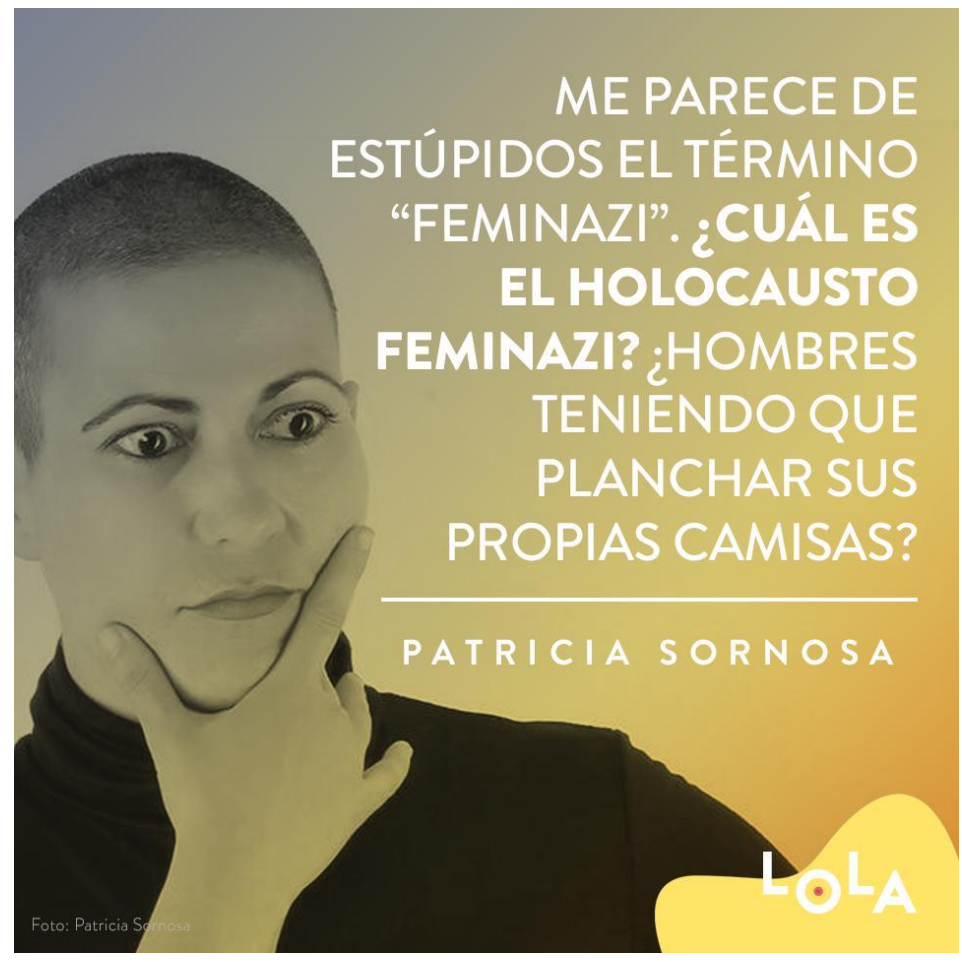

Figure 7-LOLA, August 13th 2018
The second most successful picture was a quote by actress, theatre director and comedian Patricia Sornosa, accompanied by a photo of the actress and the logo of the page. The topic is once again a joke, but it deals with the pejorative term "feminazi", which is often used to offend feminists by considering them too radical or extreme.

The quote says: "The term «feminazi» sounds stupid to me. What is the feminazi holocaust? Men having to iron their own shirts?". Once more humour plays an 
important role online: the reactions registered are nine thousand seven hundred, the shares reached eight thousand two hundred, and the comments were six hundred forty one.

Another picture which gained a discreet success was another quote, and it was selected because it was a quote from a world-wide celebrity like Madonna, which can easily represent pop culture and the type of pop feminism that her words suppose.

«I'm strong, I'm ambitious and I know exactly what I want. If that makes me a bitch...fine» recites figure 8 , which proposes the type of feminism for women who can achieve whatever they want through empowerment. It is the same type of pop feminism that Freeda media suggests to its audience.

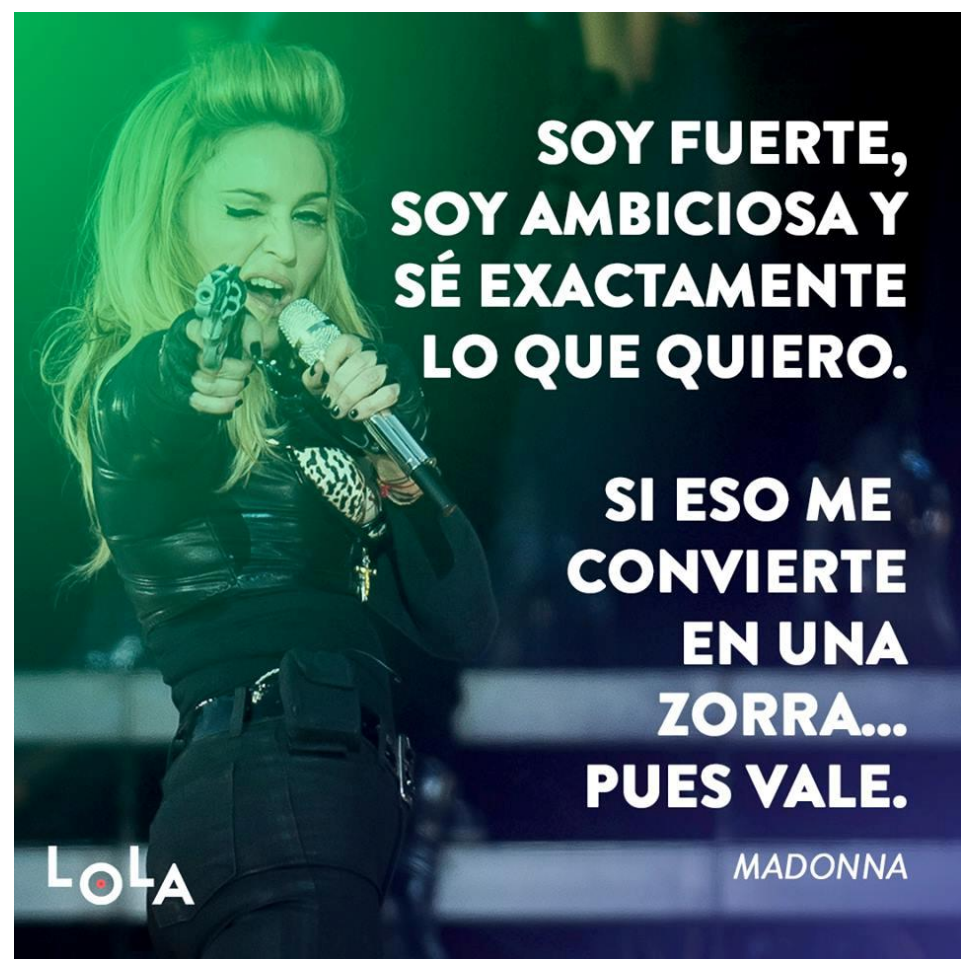

Figure 8 - LOLA, January 16th 2018

(2) shannonhspence

Las chicas que se desmaquillan cuando llegan a casa borrachísimas después de una noche de fiesta son la clase de gente que podría cometer el asesinato perfecto

21.438 Retweets 122.403 Me gusta

20000000

Figure 8 - LOLA, January 16th 2018

Finally, the last picture that was considered illustrates another screenshot, this time from the social network Twitter, on a pink background. In Figure 9, the content is once again humorous, as it says:

"Girls who take off their make-up when they get home drunk after a night of partying, are the type of people who could commit the perfect murder».

Hyperbolic humour tends to be very common on the internet, and it usually exaggerates the reality of a situation in order to achieve a comical effect. Memes in particular utilise a great amount of hyperboles in order to spread more easily; as Carlos Mauricio Castaño Díaz 
(2013:96) explains, an internet meme can be a phrase, an image or video that "can be created or based in a real life event that spreads through the internet causing people to replicate it. Sometimes it spreads in the same way and sometimes it spreads by means of change."

The large majority of images shared on social networks nowadays are memes, and pages like LOLA and Freeda are not the only ones which exploit the phenomenon to reach more views, reactions and shares.

\subsubsection{ARTICLES}

During its existence, LOLA had a little section in the Buzzfeed.com website, where it shared articles, listicles, tests and reviews of books, films or series. The following part will review some of those pieces, considering the topic, the number of interactions and the type of article concerned.

The first article that will be taken into consideration was titled "Las mujeres ya sabemos que este es un mundo hostil para nosotras: no somos imbéciles" ("Us women already know that this is an hostile world for us: we're not stupid"). It was shared on Facebook the $18^{\text {th }}$ December 2018, and it acknowledged the news of the murder of Spanish teacher Laura Luelmo, which greatly affected the public opinion. The author took the opportunity to debate the question of women's safety in society and the contradiction that too often emerges in cases like this: women are either exaggerated when they are afraid of walking back home alone at night, or too incautious for walking alone at night. The article underlines the need to reconsider the centre of the conversation: not thrusting the guilt upon women who suffer violence, but rather educating men who are violent.

The style of the article is explicit and blunt, it speaks in first person and directly to the readers in an overtly polemic tone:

"Las mujeres ya sabemos que este es un mundo hostil para nosotras. No somos imbéciles. No nos hemos caído de ningún guindo. Ni vivimos en casitas de porcelana con almohadones hechos de algodón de azúcar."

"Us women already know that this is an hostile world for us. We're not stupid. We weren't born yesterday. Nor we live in porcelain houses with cotton-candy pillowcases.” 
Out of all the articles shared by LOLA, this was the most clicked: it gained five thousand four hundred reactions, two hundred and three comments, ten thousand shares on the fourth time it was shared.

The second article selected wants to represent the type of pieces that Buzzfeed in most known for, the so called "listicles". There is a total of fifty articles published in the section of Buzzfeed's website dedicated to LOLA, and the $34 \%$ of it is composed of this kind of fast articles. The most successful of this group was titled " 11 cuentos infantiles que convertirán a tu hija en un ser libre y sabio" ("11 children tales that will turn your daughter in a free and wise person") and, as clearly expressed in the title, it lists eleven child books with strong, brave protagonists and feminist themes such as overcoming complexes, embracing differences and breaking gender stereotypes. The content offered is meagre, as the listicle is made of only titles followed by the image of a cover book and a couple of lines describing the plot of the story. It can be argued that the reason behind this type of articles is the ease in writing them and the speed in reading them.

Finally, the third article considered was titled "Tenemos que hablar de la única princesa Disney que de verdad importa: Nani, la hermana de Lilo" ("We need to talk of the only Disney princess that really matters: Nani, Lilo's sister"). This one was specifically chosen for its popular culture topic and the clear similarity with Freeda's post about "Fantaghirò". The article does not enumerate points, but it still appears in the form of a list, with short sentences separated each time by an image or a gif taken from the Disney film "Lilo \& Stitch". Nani, the character considered, is described as a positive example for girls, as somewhat a feminist icon for being slightly different from the other typical representations of princesses and girls in the Disney universe, and therefore empowering. As Andi Zeisler (2016:169) states, it seems that nowadays everything that a woman does can be considered "empowering", especially if there are commercial motives behind. In the next section, this dissertation will discuss the results of the contents analysed and compare the two Facebook pages. 


\section{RESULTS}

This chapter includes the results related to the analysis of some examples of the two pop feminist Facebook pages Freeda and LOLA. The examples offered in the analysis section were meant to highlight the type of content shared more frequently and, through the examination of videos, images and articles, identify the characteristics of pop feminism on social media. The findings generally followed the typical aspects of pop feminism, postfeminism and neoliberal feminism: in fact, the data considered were permeated with individualism, personal choice and empowerment. Nonetheless, some key themes emerged insistently from the observation of the examples and this research opted to divide them in three main topics. The pop feminist language in the cases considered was characterised by:

- a recurring discourse of empowerment;

- the presence of advertisement and femvertising;

- references to pop culture and a humorous, fun attitude.

\subsection{EMPOWERMENT}

In the beginning of this research, some attention was dedicated to the importance that the discourse of empowerment had in neoliberalism, postfeminism, and consequently in pop feminism. Both Freeda and LOLA offered clear cases of girl empowerment through the words, quotes and the positive approach used to treat different themes.

According to Zeisler (2016:169), "empowerment has become a way to signify a particularly female way of being that's both gender-essentialist [...] and commercially motivated". That is to say, the concept of empowerment is deeply connected to a so-called choice feminism, in which anything can be considered feminist if a self-labelled feminist chooses to do so. This type of marketplace feminism, however, seems to use this empowerment strategy not to engage with women, but rather with potential customers and in the examples provided by this research, empowerment has been found on several occasions.

Freeda's editorial mission, according to its LinkedIn profile and to its editor in chief Daria Bernardoni, is “to spread real women's stories to inspire positive change and impact society at large" $" 14$. After analysing the content posted by the page and highlighting some examples in this research, it is possible to confirm that the company is carrying out the

\footnotetext{
${ }^{14}$ Freeda, 2019, User profile, LinkedIn, Last Accessed: $11^{\text {th }}$ August 2019. $<$ https://www.linkedin.com/company/Freeda-media/about/>
} 
objective very thoroughly. In fact, it has been shown that the company especially promotes women's individual stories through videos. The women interviewed in Freeda's short videos are both chosen among celebrities and everyday people. This is a relevant detail, because it serves two purposes: on the one hand, it offers examples of "people who made it", both among common people and celebrities; on the other hand, it sustains the mentality of "having it all" (Slaughter, 2012), which expects women to find an equilibrium between family and career in order to be happy. Such content demonstrates how Freeda's pop feminism is aimed at promoting women who had success in spite of their personal struggles, no matter who they are: the intention corresponds then with the one supported by third and fourth wave feminism, where mainstream feminism inserts itself. That is to say, empowering women and assuring them that they have the power of choice, when actually they are offered a false sense of power through consumption (McRobbie, 1997, 2007).

In the first video example offered for Freeda, Francesca Vecchioni is the protagonist and narrates the aim of her association, whose scope is to promote inclusivity and diversity. Her words have a considerable weight not only because of the theme she is confronting, but also because she is a rather known figure in Italy. She is in fact the daughter of famous singer and songwriter Roberto Vecchioni, and she is known to the tabloids for her coming-out as a lesbian ${ }^{15}$. The fact that she is already to some extent known to the public, makes her words resonate more through the screen. Moreover, the topic of the video and of her association is particularly relevant as it deals with the inclusion of diversity, and in particular with the acceptance of sexual orientation and coming-out. It is still a sensitive theme to discuss, especially in Italy, a country where more and more people start identifying as lesbian, gay or bisexual, but where - according to a 2019 OECD report - homosexuality has become lately less tolerated ${ }^{1617}$. Vecchioni's words then become an example of a woman, who is an activist, but also a mum (as she specifies at the beginning of the video), daughter to an important artist,

\footnotetext{
${ }^{15}$ Monnis, Monica. (2019). Di come la figlia di Roberto Vecchioni ha imparato a diventare una paladina della diversity. [online] ELLE. Available at: https://www.elle.com/it/magazine/storie-di-donne/a27649972/robertovecchioni-figlia-francesca-vecchioni [Accessed 15 Sep. 2019].

${ }^{16}$ Info Data. (2019). Blog | Ecco come è considerata l'omosessualità in Italia - Info Data. [online] Available at: https://www.infodata.ilsole24ore.com/2019/05/05/considerata-lomosessualita-italia/?refresh_ce=1 [Last Accessed: 12 Aug. 2019].

${ }^{17}$ Oecd.org. (2019). Society at a Glance 2019 - OECD Social Indicators - en - OECD. [online] Available at: https://www.oecd.org/social/society-at-a-glance-19991290.htm [Last Accessed: 12 Aug. 2019].
} 
lesbian in a country where it is not always well seen to be out and proud: she is fighting the system and having it all, Freeda seems to suggest with its girl empowering narrative.

Girl empowerment also comes from the second video, where the cyclist Virginia Cancellieri is shown excelling in a supposedly male sport such as cycling. The empowering message is deeply connected with the idea that a girl can also be good at those activities, which were once mainly - if not exclusively - addressed to men. The intention of this discourse would not be damaging per se, but it assumes a different meaning if connected to an advertisement as it happens in this case. Themes that belong simultaneously to postfeminism, third wave feminism and neoliberal feminism intersect the video and the words of Cancellieri: she connects her empowerment as a sportswoman with words such as "goal", "freedom" and "independence", which in the collective consciousness recall the ideal of a successful life.

Thus, the neoliberal belief that happiness can only be reached through some degree of success makes Freeda share women stories of any kind, making them "empowering" just for the fact that women are carrying them out. It is the case of the third video selected, in which tattoo artist "La Bigotta" shows how she was able to overcome some past difficulties and to deal with the prejudices linked to having your body inked. Tattoos are part of popular culture all around the world, yet sometimes still not well seen in certain contexts: they can easily become an instrument of western empowerment, as they are in Freeda's video.

Among Freeda's content, the discourse of empowerment can be also found in pictures and articles: in Figure 3, the quote from Emma Watson is meant to encourage girls to be warriors rather than princesses, protagonists rather than sidekicks by following the example of Hermione - character from the Harry Potter saga impersonated on screen by Watson herself. Similar qualities are offered by the character of Fantaghirò in the article "Being Fantaghirò": this kind of discourse offers girls a different kind of role model, more active, more central to the story, stronger and more clever.

In regard to $L O L A$, girls and women are empowered through the same means of Freeda, yet it presents some slight differences. For instance, the most clicked video titled "«Es que las gordas..." Por favor, CÁLLATE.»»" deals with girl empowerment through body positivity: the images shown in the short video are meant to deconstruct society's beauty standards, which are always strongly connected to a thin and sporty body. The title of the video itself seems to take a strong position with the imperative "Cállate", "Shut up", offering no room for any reply. The words picked to illustrate the topic are few but straightforward: the video alternates cliché, offensive sentences usually directed to overweight women such as "A fattie cannot be chic", 
“A fattie shouldn't wear bikinis" and "You should lose weight, you'd be happier" with photos of happy, healthy women contradicting those statements. The manner in which the topic is presented traces the characteristics of pop feminism on social media: short video with background music, irony and colourful content meant to attract the users' attention. However, the position defended by the page is a clearly feminist one and the absence of a marketing endorsement could indicate a more activist stance compared to Freeda's and a genuine support to a positive self-perception.

From the analysis of the selected data, it appeared that one way for pop feminism to empower girls is also through education. Indeed, another one of LOLA's most successful videos offered to debunk the myths around virginity. Empowerment then lies in the knowledge of your own body, LOLA suggests, without believing urban legends. Although part of the content containing empowering messages could actually be considered feminist, LOLA also proposed quotes from celebrities that are profoundly rooted in neoliberalism. In Figure 8, Madonna's quote set an example of neoliberal feminism, which turns to empowerment as a discourse for women to become anything they want. By using the word "bitch", Madonna is on one hand taking back a historically offensive term and resignifying it into an empowered adjective; on the other hand, she is implying that women, by embracing their ambition and inner strength, can reach whatever objective they want. It is a type of discourse that matches the neoliberal belief that the subject is the only responsible of their own success, forgetting the socio-economic and cultural variables involved.

\subsection{FEMVERTISING}

Another element that stood out in the analysis of the data was the presence of advertisements in some of the posts shared. As stated in the beginning, it was possible to actively observe this only on Freeda's page, because LOLA had already been closed at the time of this research; therefore, the Facebook analytics tool was not able to show any running advertising on the content posted. As this dissertation could only speculate on the presence of advertising on LOLA, the choice was to focus on Freeda only.

Among the examples, two were explicitly chosen because of the presence of branded content. Firstly, the "Freeda's game changers: Virginia Cancellieri" video, considered in the previous section as an instance of empowerment discourse, was also appropriate to describe the role that femvertising plays in pop feminism. The video displayed a collaboration with the Volkswagen brand, in particular with the car model "Volkswagen Up!". The language 
associated with the cyclist - as earlier explained - were terms linked to girl empowerment. Subsequently, girl empowerment discourse is functional to the type of advertisement proposed by a pop feminist editor such as Freeda. As a matter of fact, the target audience of Freeda is composed of women between 18 and 34 years old (Giovani Imprenditori Confindustria, 2017), who are already used to and expect to find a specific type of content and topics when scrolling through the posts. The current research observed that pop feminism online, in the case of Freeda, exploits the strategies of branded content and native advertising to create a dialogue between a brand and their own audience. The example provided in Figure 2 shows how subtle and non-intrusive this type of advertising can be. In fact, the picture presents a funny and relatable situation, while the name of the brand (Nivea) and the details of the product (a facial mask) appear smaller. The audience of the content is therefore more inclined to connect to the everyday life situation, rather than perceiving the image as a piece of advertisement.

In both examples analysed it is interesting to notice that Freeda seems to exploit some characteristics of pop feminism without ever making explicit or using the word "feminism". Instead, the postfeminist and neoliberal concepts that are used are freedom, independence, strength; the features involved are connected to the idea that women have the power of choice over their activities, be it a typically male sport such as cycling, or the possibility of staying at home taking care of themselves and their own femininity. It has been noticed that the platform aims to empower women by telling them they are perfect as they are. However, the examples of native advertising show how femininity on Freeda often seems to still be connected with self-care and beauty: this reiteration of old stereotypes could prove that pop feminism combined with advertising does not challenge the existing system.

\subsection{POP CULTURE AND HUMOUR}

The third recurring element that emerged from the data observed was the constant repetition of humour and the presence of references to popular culture. Both pages resorted to jokes, memes, and quotes from pop culture to handle different topics. Zeisler (2016) states that pop feminism has become fun and popular to be more acceptable and attractive to the masses, and that is what the content shared by Freeda and LOLA confirmed. References to the realm of pop culture were common in both pages, regardless of the issue. Some examples were the articles of Freeda: they dealt with heterogeneous topics, which contained sports, television and politics. The subjects treated all belonged to the sphere of pop culture. LOLA used pop culture references in the article "We need to talk of the only Disney princess that really matters: 
Nani, Lilo's sister", where the character is described as an empowering example of strength and family bonding. Pop references appear also in the video "Virginity is a lie" in the form of GIFs - small animated images - that serve as brief sarcastic or funny comments to what Beatriz Serrano is explaining in the video. Such references mostly recall tv series' characters and cinema, and its aim is to make the topic more acceptable, easy and fun to watch. Jokes and gags were also present in Freeda's article "Being Fantaghirò", while visual references to the tv series "Stranger Things" appeared in the article "If the abortion law is approved, Netflix will leave Georgia".

Fun and humour were found to be the link between these two pop feminist pages: the vast majority of the topics shared were treated with a fun, light-hearted attitude to connect with the users on arguments that could range from easier to slightly more complex ones. LOLA in particular exploited its funny pictures to convey pop feminist themes, such as the critique to the term "feminazi" (figure 7) through a joke by comedian Patricia Sornosa. The feminist message in the joke is clear, but the humour makes it easier to share, and as a consequence allows the message to potentially reach a greater audience on social media. Feminism could then really exploit this means as a new tool to make its values and ideas spread in an easier and more attractive way.

\subsection{DISCUSSION}

Following the analysis and the results obtained from the observation of the data, this section will propose an interpretation of said data and discuss them.

Since the beginning, this piece of research was aware of the strong contradictions permeating the concept of mainstream/pop feminism: it has a clear and great potential of reaching a vast number of people with its themes, while at the same time it often runs the risk of watering these themes down up to the point of making them lose all of their political and activist strength.

Initially, the main expectation was to prove that the language of pop feminist media on the internet was essentially biased, in particular by the presence of advertising and the exploitation of the feminist trend by brands. Yet, the overall idea was that pop feminism could still be positive for the masses. After months of observation and study though, the expectations were only partially met and the topic of popular feminism offered more than one cause for reflection. The ultimate conclusion that I reached in regard to the language of pop feminism can be illustrated with the concept of "ambivalence" (Banet-Weiser, Gill and Rottenberg, 
2019; Berlant, 2008:2): pop feminism, because of its contradictions, has to be seen and understood through ambivalence. Trying to reduce it into a binary opposition between more authentic feminism and less authentic feminism would be counter-productive.

Before diving into the conclusion, this work has explained that the data collected presented some recurring key themes. These are especially relevant to this dissertation and to the initial research question, which intended to conduct a study of mainstream feminism online. Such themes - empowerment, femvertising and humour - coincide with the description and definition of pop feminism offered in the theoretical framework section (section 1.2). Consequently, to understand why this particular set of themes describes pop feminism while others don't, it is necessary to remember the context in which pop feminism started to exist, and after that to illustrate the concept of "economy of visibility" (Banet-Weiser, 2018). In fact, as proven by this thesis, pop feminism and the language it uses are deeply intertwined with self-empowerment, freedom and choice, all of them aspects that belong to third and fourth wave feminisms, but also apply to postfeminism and to the hyper individualism of neoliberal feminism. Considering such a context, one can comprehend why pages like Freeda and LOLA developed some topics more than others. For instance, as stated earlier, pop feminism in the form of the Facebook pages analysed showed a persistent attempt to empower the target audience. The concept of empowering girls and women is linked to a positive attitude requested by society in order to "have it all" and to be successful in life. Empowerment appeared to one of the pillars of pop feminism, as it is meant to make its users feel good: in the example concerning overweight people and body positivity, LOLA offered a message of acceptance for those bodies that do not follow the norm, taunting a particular type of criticism towards fat bodies and sarcastically mocking those people who still do not accept them as part of a variety of human bodies. In turn, Freeda intended to empower women by sharing other women's stories, as in the case of the video "Woman crush on: La Bigotta", which can be considered another case of light attempt at body positivity. Instead of dealing with overweight people though, the focus is on tattoos and on how the protagonist of the story had to be accepted for her inked choices. The constant empowerment offered in this type of feminism through entitling words and positive images can be seen as the neoliberal try to resolve gender inequalities by positioning women as individualised, entrepreneurial and empowered subjects, who are able to make choices and balance family and work (Rottenberg, 2014:22). This precise subject is essential to the pop feminist discourse, which exists within an economy of visibility, as Banet-Weiser explains (2018). This economy of visibility is a system in which pop 
feminism expressions and practices are circulated, a site where the new currency is made of followers, likes and shares. Such a description perfectly suits the pop feminism expressed by the two Facebook pages analysed by this work. Moreover, pop feminism differs from other feminist practices precisely because it presents itself as a "media that is widely visible and accessible" (Banet-Weiser, Gill and Rottenberg, 2019). Visibility needs to constantly grow because it is the marker of popularity and of online success: for companies like Freeda and Buzzfeed, creating content that can go viral and generate more shares and reactions is fundamental, because the income and the advantages they are looking for are generated by the interactions with their posts.

Therefore, the notion of visibility can be of help in understanding why some features appeared more regularly in the data. Empowerment has become a discourse widely used in mainstream feminism, as its positive messages can easily engage with the target; humour and funny quotes are the best means to spread content on the internet, where users often look for diversion and are more likely to share an amusing and entertaining post rather than others; finally, femvertising is both a consequence and a cause for visibility. In fact, the growing visibility of a page like Freeda attracts brands and investors that want to use the platform to advertise their products. Still, at the same time, the presence of advertisement on pop feminist media can help increase the visibility of the page, especially if the brand in question is an important one.

Thus, visibility is the backbone of pop feminism, which constantly looks for popularity and thanks to that can rely to a wide and large pool of users as a target. If at first such an option might seem positive and useful to share feminist ideas on the internet, it must be remembered that by accepting to exist inside the economy of visibility, pop feminism relies on "platform capitalism" (Banet-Weiser, Gill and Rottenberg, 2019). That is to say, the contents of feminism found on social media are influenced by media and entertainment platforms. In other words, most of the types of feminist expressions offered online on pages like Freeda and LOLA are inevitably conditioned by business models. Furthermore, one has to consider that having visibility does not necessarily imply a change, because on the one hand being visible is strongly associated with the contemporary economy and its capitalist structures; on the other hand, visibility has become an end in itself (Gray, 2013) and, according to Banet-Weiser (2018), "the most popular feminisms are the ones that don't challenge deep structures of inequities". 
Hence, what my work has discovered through the observation of the content of Freeda and LOLA has been a repetition of the same themes and features caused by the need of visibility. The type of language they used was similar and was also deeply influenced by the economy of visibility of social media. The two pages were essentially the same, even if some slight differences were noticed. Their main dissimilarities were found in the number of followers, in the presence of advertising and in the some of the words used in a particular case. First of all, Freeda presented a higher number of followers and a broader audience in comparison with LOLA. This was interpreted in the light of the different life span that the two pages had: Freeda is a page with a still on-going activity, while the other shut down in January 2019, stopping any production of new content. This reason was also behind the amount of running advertisements encountered: the Italian page had numerous instances of branded content signalled by the Facebook Ad Library tool, both in the form of video and picture that stayed on the page even after the advertisement stopped running. On the contrary, LOLA did not present sponsored content on its Facebook page. The absence of advertising, however, could be explained by the short life that the page had, and the consequent impossibility to retrieve advertisement information once the page stopped being active; by the fact that LOLA was a spin-off page of Buzzfeed Spain and therefore advertising could be reserved for the main page. In any case, it would be wrong assuming that LOLA had different feminist aims compared to Freeda because of the inferior number of advertisements found, because the American company Buzzfeed exploits and uses advertising in their content with frequency. It would make more sense to presume that the mission of Buzzfeed Spain and Buzzfeed LOLA mimic the mission of the head page Buzzfeed.

The main differences came in the way some topics were tackled: while Freeda always revealed to respect the features of pop feminism and neoliberal feminism, without straying towards stronger feminist positions, LOLA dared to use fiercer words at times. For example, in the article "Us women already know that this is an hostile world for us: we're not stupid", editor Beatriz Serrano takes a feminist position while talking of the case of murder of Laura Luelmo. She declares that it is not women who do not pay enough attention when getting out, but rather men are the ones who would need a better education in order to respect women. Other examples were found in the videos of LOLA, which dealt with virginity, overweight and politics in a pop feminist way that simultaneously allowed the user to reflect. They were in fact slightly longer and more focused on feminist themes in place of just individualistic women stories. Such a position should be natural, this work dares to affirm, but nothing similar in 
tones was found while examining Freeda, which instead remained always more neoliberal than feminist. LOLA still, considering the other examples provided in the data, also remains a pop feminist page. The slight discrepancy between the Italian and the Spanish page comes from the different consideration that feminism has got in the media in these two countries: while it is true that worldwide feminism has become "hot" and "cool", there is still a difference in how the topic of feminism is perceived in Italy and in Spain. Italy shows even now some resistance when it comes to dealing with topics related to gender, women and feminism. Just to offer an example, in those cases concerning crimes or feminicide, the media often focuses on the victim rather than on the aggressor ${ }^{1819}$. Moreover, the word "feminism" is still looked at suspiciously in my country, in particular by the public opinion. On the contrary, Spain seems to be more open to the movement, and this is reflected in the exploitation of feminism in political campaigns ${ }^{20}$, in the great success of the Women's March on the $8^{\text {th }}$ of $\mathrm{March}^{21}$, and of course in how a pop feminist Facebook page deals with certain topics.

To conclude this part, Freeda and LOLA's analysis of the data proved to conform to the characteristics of pop feminism in all of their aspects, even with some occasional slight difference between the two. The language they used in the data considered has been said to be influenced by the necessity of visibility, and the connection between visibility, popularity and advertising was highlighted.

These results of course presented some degree of limitations: in order to reach a deeper and more thorough analysis of the language of pop feminism this work would have needed a greater amount of data, but because of scarcity of time and space, it was decided to stick to a smaller amount of samples. In addition to that, the unexpected closure of LOLA rendered

\footnotetext{
${ }^{18}$ Soncini, Guia. (2017). Opinion | The Failure of Italian Feminism. [online] Nytimes.com. Available at: https://www.nytimes.com/2017/10/26/opinion/italian-feminism-asia-argento-weinstein.html [Last Accessed: 9 Sep. 2019].

${ }^{19}$ Torrisi, Claudia. (2017). Monsters, jealousy and "sick love” — how the Italian media covers violence against women. [online] openDemocracy. Available at: https://www.opendemocracy.net/en/5050/italian-mediaviolence-against-women/ [Last Accessed: 9 Sep. 2019].

${ }^{20}$ France 24. (2019). Feminism is the word in Spain's electoral campaign. [online] Available at: https://www.france24.com/en/20190306-feminism-word-spains-electoral-campaign [Last Accessed: 9 Sep. 2019].

${ }^{21}$ Belaza, Mónica. (2019). Why Women's Day was such a runaway success in Spain. [online] EL PAÍS. Available at: https://elpais.com/elpais/2018/03/21/inenglish/1521624982_050188.html [Last Accessed: 9 Sep. 2019].
} 
impossible a comparison between types of femvertising. However, such details could be explored in future research, as it will be suggested in the next and final section. 


\section{CONCLUSIONS}

This dissertation aimed to analyse two Facebook pages that self-presented themselves as pop feminist. The intended objectives were a definition of pop feminism and femvertising through the observation of the Facebook pages Freeda Media and Buzzfeed LOLA and their language on social media. To do that, it firstly considered the context in which pop feminism came to exist and the influence it was subjected to by similar currents and movements such as third and fourth wave feminism, neoliberalism and postfeminism. After recognising the importance of that background, some attention was dedicated to the concept of femvertising, which it has been shown to be very relevant in pop feminism.

Then, the description of Freeda and Buzzfeed LOLA followed, along with the presentation and the analysis of the data. From the analysis and discussion emerged three typical features that the content of the two media had in common: a recurring discourse of empowerment, the presence of femvertising, and the use of humour and references to pop culture. This was explained through the idea expressed by Sarah Banet-Weiser (2018), that is the economy of visibility, which pop feminism needs in order to maintain its popularity online. Taking a look at the findings, it also became clear that pop feminism possesses a strong deal of contradictions within itself. Its existence inside of the patriarchal system and its claim to be feminist at the same time without changing or challenging the existing order, leaves room for doubts about its usefulness and benefit to the feminist movement.

However, the final consideration that came after the analysis and discussion of the data, was that pop feminism needs to be examined and understood with a lens of ambivalence (Banet-Weiser, Gill and Rottenberg, 2019). Its presence online and on social media causes debates for many reasons, for its lack of political strength and of activism; yet, one should consider that there is no such thing as a correct type of feminism which is better than the others. Instead, the users should consume pop feminist content responsibly and with selfconsciousness, so that in the future it could be possible to understand its deficiencies and construct a different kind of popular feminism. It would be a type of popular feminism, which could be more about the people and activism: one that, to say it in Silvia Federici's words (2018), could allow the development of a collective subject instead of the individual pop feminist subject.

Even though this work was able to present some interesting results, limitations were encountered during the research. Because of time and space, this dissertation could only focus on a very small group of data for its analysis: for this reason, the results obtained are partial 
and do not want to extend to other pop feminist instances that could be found online. Besides, the examples of pop feminism analysed are both European, therefore pertaining to a specific section of the Western context.

Future research might be able to widen the amount of available data and might focus on other examples of mainstream and pop feminism. Said examples might come from outside Europe or even explore media outside the Western context, in order to supply a comparison between mainstream feminisms coming from different parts of the world. Finally, future research could open up the discussion and reflection of inserting more activist language in pop feminist settings, so that visibility could be exploited to really spread feminist topics. 


\section{BIBLIOGRAPHY AND FURTHER READINGS}

- Åkestam, Nina, Rosengren, Sara, and Dahlen, Micael. (2017). Advertising "like a girl": Toward a better understanding of "femvertising" and its effects. Psychology \& Marketing, 34(8), 795-806.

- Aronson, Pamela. (2003). Feminists or “postfeminists"? Young women's attitudes toward feminism and gender relations. Gender \& Society, 17(6), 903-922.

- Artz, Nancy, and Venkatesh, Alladi. (1991). Gender Representation in Advertising. NA Advances in Consumer Research Volume 18. Eds. Rebecca H. Holman and Michael R. Solomon, Provo, UT: Association for Consumer Research, pp. 618-623.

- Banet-Weiser, Sarah. (2018). Empowered: Popular Feminism And Popular Misogyny. Durham: Duke University Press.

- Banet-Weiser, Sarah, Gill, Rosalind, and Rottenberg, Catherine. (2019). Postfeminism, popular feminism and neoliberal feminism? Sarah Banet-Weiser, Rosalind Gill and Catherine Rottenberg in conversation. Feminist Theory, $0(0), 1-22$. Published online first. $23^{\text {rd }}$ April. doi: 10.1177/1464700119842555. [Last Accessed: $13^{\text {th }}$ September 2019.]

- Berlant, Lauren. (2008). The Female Complaint: The Unfinished Business Of Sentimentality In American Culture. Durham and London: Duke University Press.

- Castaño, Díaz, Carlos Mauricio. (2013). Defining And Characterizing The Concept Of Internet Meme. Revista CES Psicología, 6(2), pp. 82-104. [Last Accessed: $13^{\text {th }}$ September 2019].

- Chamberlain, Prudence. (2017). The Feminist Fourth Wave: Affective Temporality. New York: Palgrave Macmillan.

- Ciambriello, Roo. (2014). How Ads That Empower Women Are Boosting Sales And Bettering The Industry. ADWEEK. Retrieved from https://www.adweek.com/brandmarketing/how-ads-empower-women-are-boosting-sales-and-bettering-industry-160539/. [Last Accessed: $13^{\text {th }}$ September 2019].

- Cochrane, Kira. (2013). All The Rebel Women. London: Guardian Books.

- D'Enbeau, Suzy. (2011). Sex, feminism, and advertising: The politics of advertising feminism in a competitive marketplace. Journal of Communication Inquiry, 35(1), 53-69.

- Edut, Ophira. (1999). “Barbie Girls Rule?”. Bitch, Winter 1999, p. 16.

- Eisend, Martin. (2010). A Meta-analysis Of Gender Roles In Advertising. Journal of the Academy of Marketing Science, 38(4), pp. 418-440. 
- Eisenstein, Zillah (1996) Hatreds: Racialized and Sexualized Conflicts on the 21 st Century. New York: Routledge.

- Faludi, Susan. (1992). Backlash: The Undeclared War Against Women. London: Vintage.

- Farhall, Kate. (2015). The Contradictions of Pop Feminism (pp. 95-104). In Miranda Kiraly and Meagan Tyler (Eds.), Freedom Fallacy. Ballarat: Connor Court Publishing.

- Federici, Silvia, and Peter Linebaugh. (2018). Re-enchanting the World: Feminism and the Politics of the Commons. Oakland, CA: PM Press.

- Fester, Gertrude. (1994). Women's Rights Are Human Rights. Agenda: Empowering Women for Gender Equity. 20: 76-79. DOI: 10.2307/4065874 [Last Accessed: 13 ${ }^{\text {th }}$ September 2019].

- Gallego, Joana. (2009). La construcción del género a través de la publicidad. En Universitat de Girona (Eds.), Actes de Congènere: la representación de gènere a la publicitat del segle XXI. Girona, España: Universitat de Girona.

- Gill, Rosalind, and Scharff, Christina. (Eds.). (2013). New femininities: Postfeminism, neoliberalism and subjectivity. Houndmills: Palgrave Macmillan.

- Grove, George. (1980). The New Grove dictionary of music and musicians (Vol. 5). London: Macmillan.

- Harvey, David. (2007). A brief history of neoliberalism. New York: Oxford University Press.

- Holborow, Marnie. (2015). Language and neoliberalism. London and New York: Routledge.

- Humm, Maggie. (1990). The dictionary of feminist theory. Columbus: Ohio State University Press, p. 251.

- Kiraly, Miranda, and Tyler, Meagan. (2015). Freedom fallacy. Ballarat: Connor Court Publishing.

- Klinger, Barbara. (2006). Beyond the multiplex: Cinema, new technologies, and the home. Berkeley: University of California Press.

- Krolokke, Charlotte, and Sorensen, Anne Scott. (2005). From Suffragettes to Grrls. In Gender Communication Theories and Analyses: From Silence to Performance. London: Sage.

- Lakoff, Robin. (1973). Language and Woman's Place. Language in Society, Vol. 2, No. 1., pp. 45-80. University of Cambridge: Cambridge University Press. Available at: <http://www.jstor.org/stable/4166707> [Last Accessed: 13 ${ }^{\text {th }}$ September 2019]. 
- Lazar, Michelle M. (Ed.). (2005). Feminist critical discourse analysis: Gender, power and ideology in discourse. Basingstoke: Palgrave.

- Maclaran, Pauline. (2012). Marketing and feminism in historic perspective. Journal of Historical Research in Marketing, 4(3), 462-469.

- McRobbie, Angela. (1997). Bridging the gap: Feminism, fashion, and consumption. Feminist Review, 55, 73-89.

- McRobbie, Angela. (2004). Post-feminism and popular culture. Feminist media studies, 4(3), 255-264.

- McRobbie, Angela. (2007). Top girls? Young women and the post-feminist sexual contract. Cultural Studies, 21, 718-737.

- McRobbie, Angela. (2009). The aftermath offeminism: Gender, culture and social change. London: Sage.

- Mills, Sara, and Mullany, Louise. (2011). Language, gender and feminism. Abingdon, Oxon: Routledge.

- Munro, Ealasaid. (2013). Feminism: A Fourth Wave?. Political Insight, 4(2), pp. 22-25.

- Rottenberg, Catherine. (2014). The Rise of Neoliberal Feminism, Cultural Studies, 28:3, 418-437, DOI: 10.1080/09502386.2013.857361 [Last Accessed: $13^{\text {th }}$ September 2019]

- Schulte, Stephanie Ricker. (2011). Surfing Feminism's Online Wave: The Internet and the Future of Feminism. Feminist Studies, vol. 37, no. 3, pp. 727-744. Available at: <www.jstor.org/stable/23069943>.

- Sheehan, Kim Bartel. (2013). Controversies in contemporary advertising. Thousand Oaks, CA: Sage.

- Slaughter, A. M. (2012, July-August). Why women still can't have it all. The Atlantic, 310(1), 84-102. Retrieved at:

<https://www.theatlantic.com/magazine/archive/2012/07/why-women-still-cant-have-itall/309020/>

- Steinem, Gloria. (1965). The Ins and Outs of Pop Culture. Life, 20, 72-89.

- Trier-Bieniek, Adrienne and Leavy, Patricia. (2014). Introduction to Gender \& Pop Culture (pp.1-26). In A. Trier-Bieniek and P. Leavy (eds.), Gender \& Pop Culture. A TextReader. Rotterdam: Sense Publishers.

- Wherry, Frederick F., and Schor, Juliet B. (Eds.). (2015). The SAGE encyclopedia of economics and society. Thousand Oaks, CA: Sage. 
- Zeisler, Andi. (2016). We were feminists once: From riot grrl to CoverGirl, the buying and selling of a political movement. New York: Public Affairs.

\section{SITOGRAPHY}

- About BuzzFeed. (2019). About BuzzFeed. [online] Available at: <https://www.buzzfeed.com/about> [Last Accessed: 17 May 2019]

- Business Dictionary, 2019. Available at : $<$ http://www.businessdictionary.com/definition/branding.html>. [Last Accessed: $15^{\text {th }}$ September 2019].

- Collinsdictionary.com. (2019). Popular culture definition and meaning | Collins English Dictionary. [online] Available at:

<https://www.collinsdictionary.com/dictionary/english/popular-culture> [Last Accessed: 12 Aug. 2019].

- Corporate.shemedia.com. (2019). [online] Available at: <http://corporate.shemedia.com/attachments/204/iBlog_Magazine-SheKnowsFemvertisingFeature.pdf> [Last Accessed: 7 Jun. 2019].

- Davidson, L. (2015). Femvertising: Advertisers cash in on \#feminism. [online] Telegraph.co.uk. Available at: <http://www.telegraph.co.uk/women/womenslife/11312629/Femvertising-Advertisers-cash-in-on-feminism.html> [Last Accessed: 7 Jun. 2019].

- Davis, Angela. (9th October 2017). Revolution today. CCCB: Centre de Cultura Contemporània de Barcelona. Available at: $<$ https://www.cccb.org/en/multimedia/videos/angela-davis/227656> [Last Accessed: $15^{\text {th }}$ September 2019]

- DINAMOpress. (2017). Ecco cosa c'è dietro Freeda - DINAMOpress. [online] Available at: <https://www.dinamopress.it/news/ecco-cosa-ce-dietro-Freeda/> [Last Accessed: 14 May 2019].

- Facebook.com. (2019). Freeda. [online] Available at:

<https://www.facebook.com/pg/Freedamedia/posts/?ref=page_internal> [Last Accessed: 14 May 2019].

- Freeda Media (2018). Woman crush on: La Bigotta. [video] Available at: <https://www.facebook.com/Freedamedia/videos/vl.175261459701827/2035430340101 614/?type=1> [Last Accessed: 24 Jun. 2019]. 
- Feder, J. Lester, and Alagna, Giulia. (2019). [online] Buzzfeednews.com. Available at: <https://www.buzzfeednews.com/article/lesterfeder/italy-war-on-women-verona-worldcongress-of-families> [Last Accessed: 8 Sep. 2019].

- Giovani Imprenditori Confindustria. (23 ${ }^{\text {rd }}$ June 2017). Daria Bernardoni - E' la new economy, bellezza! - 10 giugno 2017. [Video file]. Retrieved from <https://www.youtube.com/watch?v=y4-NQ9BK_YQ> [Last Accessed: 18 Aug. 2019].

- Giuffrida, Angela. (2019). City of love? Christian right congress in Verona divides Italy. [online] the Guardian. Available at: <https://www.theguardian.com/world/2019/mar/29/city-of-love-christian-right-congressin-verona-divides-italy-league-extremism> [Last Accessed: 18 Aug. 2019]

- Hwong, Connie. (2019). Chart of the Week: Tracking Audience and Reader Demographics. [online] Verto Analytics. Available at: <https://www.vertoanalytics.com/chart-week-tracking-news-reader-demographics/> [Last Accessed: 2 Jul. 2019].

- Medium. (2019). Qué hacía exactamente en BuzzFeed - Beatriz Serrano - Medium. [online] Available at: <https://medium.com/@ betinaserrano/qu\%C3\%A9hac\%C3\%ADa-exactamente-en-buzzfeed-23d57801d9f> [Last Accessed: 26 Jun. 2019].

- Solomon, Deborah. (2009). The Blogger and Author on the Life of Women Online. [online] Nytimes.com. Available at: $<$ https://www.nytimes.com/2009/11/15/magazine/15fob-q4-t.html> [Last Accessed 15 ${ }^{\text {th }}$ September 2019].

- Ward, M. (2006). BBC NEWS $\mid$ Technology $\mid$ How the web went world wide. [online] News.bbc.co.uk. Available at: <http://news.bbc.co.uk/2/hi/science/nature/5242252.stm> [Last Accessed: 16 Aug. 2019]. 